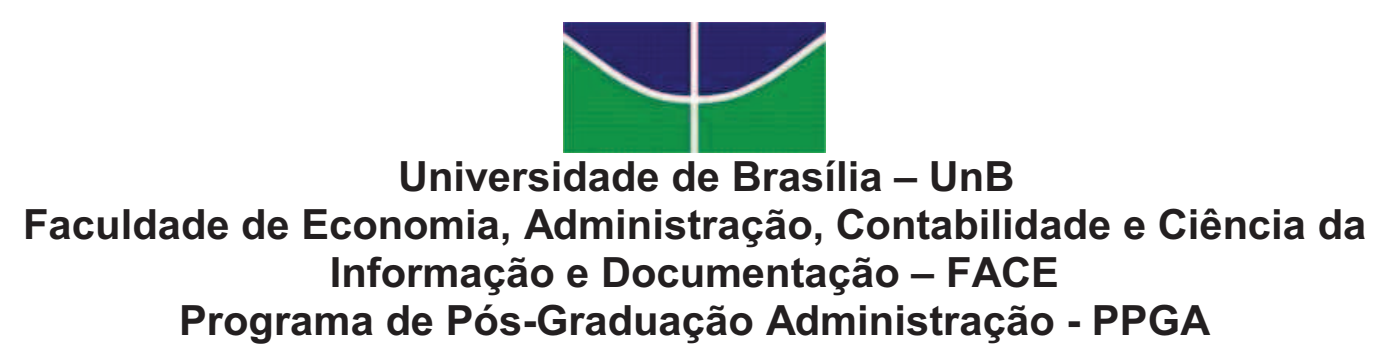

Fernanda Freires Miranda

Fontes de Mal-Estar no Trabalho e Estratégias de Mediação no Contexto do Serviço Público: Desafios e Perspectivas para a Qualidade de Vida no Trabalho 
Universidade de Brasília - UnB

Faculdade de Economia, Administração, Contabilidade e Ciência da Informação e Documentação - FACE

Programa de Pós-Graduação em Administração - PPGA

\title{
Fontes de Mal-Estar no Trabalho e Estratégias de Mediação no Contexto do Serviço Público: Desafios e Perspectivas para a Qualidade de Vida no Trabalho
}

\author{
Monografia apresentada à Faculdade de Economia, \\ Administração, Contabilidade e Ciência da Informação e \\ Documentação (FACE), da Universidade de Brasília, \\ como requisito final à obtenção do grau de Especialista \\ em Gestão Universitária.
}

Orientador: Prof. Dr. Mário César Ferreira

Fernanda Freires Miranda

Brasília, DF

Junho, 2010 
Fontes de Mal-Estar no Trabalho e Estratégias de Mediação no Contexto do Serviço Público: Desafios e Perspectivas para a Qualidade de Vida no Trabalho

Monografia apresentada à Faculdade de Economia, Administração, Contabilidade e Ciência da Informação e Documentação (FACE), da Universidade de Brasília, como requisito final à obtenção do grau de Especialista em Gestão Universitária.

Banca Examinadora

Prof. Dr. Mário César Ferreira

Orientador

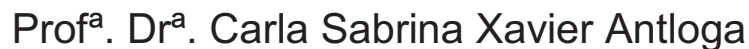

Membro da Banca 
Dedico este trabalho a Deus que me fez perseverante, pois sem ele nada seria possível e pela presença constante de suas bênçãos em minha vida. 


\section{AGRADECIMENTOS}

À Universidade de Brasília, pela oportunidade de especialização a mim oferecida.

À toda a Equipe do PPGA, pelo apoio sempre presente.

Aos doutores Professores da Universidade de Brasília

Meus sinceros agradecimentos ao Prof. Dr. Mário César Ferreira, por honrar-me, aceitando ser meu orientador e pelo especial apoio, sem o qual seria impossível levar este estudo a termo.

Ao colega de pesquisa Giovanni pela convivência e pelas idéias trocadas durante todo esse tempo.

Agradeço ao Éder pelo maior companheirismo que alguém poderia dar à alguém. É importante dizer o quanto estar a seu lado foi essencial para tornar possível este sonho. Você esteve em cada vitória conquistada e sem você, garanto que eu não teria toda esta coragem que tenho. Te amo!

À minha família por ter me ajudado a chegar até aqui.

À amiga Mônica, que foi minha grande parceira em todos os trabalhos da especialização. Obrigada por todos os momentos compartilhados. Sem eles essa trajetória teria sido mais difícil.

Aos colegas de trabalho: Claudia, Jacaré, Joelder, Elba, Douglas, Girleide pela convivência agradável e amizade.

Ao Arnaldo, diretor desta unidade Administrativa estudada, agradeço pela confiança em mim depositada.

Aos servidores e funcionários terceirizados, participantes deste estudo, pela acolhida, disponibilidade e colaboração.

A todos muito obrigada! 


\section{RESUMO}

O objetivo deste trabalho é investigar a relação entre mal-estar no trabalho, as Estratégias de Mediação Individual e Coletiva (EMIC) e a Qualidade de Vida (QVT) no Trabalho dos trabalhadores de uma Unidade do Serviço Público Federal. O quadro teórico utilizado na presente pesquisa foi fundamentado no modelo teórico da Ergonomia da Atividade que contempla três dimensões analíticas: as fontes de mal-estar no trabalho, Estratégias de Mediação e Qualidade de Vida no Trabalho. Utilizou-se como abordagem metodológica a análise documental, observações e a técnica de Grupo Focal que demandou reuniões com o diretor desta unidade administrativa, posteriormente momentos de sensibilização dos servidores públicos e funcionários terceirizados da unidade administrativa do serviço público federal, sendo dividido em dois grupos: 14 participantes da unidade sede e 12 participantes dos postos descentralizados. Os encontros dos grupos focais foram realizados em dias diferentes para cada um dos grupos se compreendeu três etapas: formulário com questões individuais (14 participantes) da unidade sede, com duração média de (20 minutos) e (12 participantes) dos postos descentralizados, com duração média de (20 minutos), subgrupos na unidade sede (5 grupos, com duração média de 40 minutos e 14 participantes) e postos descentralizados (4 grupos, com duração média de 40 minutos e 12 participantes), e síntese do grupo, na unidade sede com os (14 participantes, duração média de 40 minutos) e postos descentralizados (12 participantes, duração média de 40 minutos) com as informações obtidas pelos grupos focais foi elaborado um relatório de diagnostico do contexto de trabalho desta unidade administrativa do serviço público federal. A análise dos dados indica como a relação entre as fontes de mal-estar relacionadas às condições de trabalho (CT), à organização do trabalho (OT) e às relações socioprofissionais (RS) interfere no contexto de trabalho, dispondo as fontes de mal-estar que são observadas pelos servidores e funcionários terceirizados associadas aos respectivos modos de lidar, conseqüências e sugestões apontados pelos grupos focais. Por meio dessa visualização das fontes de mal-estar associadas a essas três variáveis (CT, OT e RS), pode-se observar a interdependência entre essas dimensões, indicando que as estratégias de mediação no contexto de trabalho para ser efetivas e conseguir reduzir as fontes de mal-estar devem levar em conta esse relacionamento entre elas. Assim, com as vivências de mal-estar no trabalho, suas conseqüências e modos de lidar identificadas na pesquisa de Grupo Focal possibilitaram em sugestões para a Qualidade de Vida no Trabalho (QVT).

Palavras-Chave: Mal-Estar no Trabalho, Estratégias de Mediação, Qualidade de Vida no Trabalho, Ergonomia da Atividade. 


\section{LISTA DE FIGURAS}

FIGURA 1- TAMPA DE PROTEÇÃO ...................................................................... 40

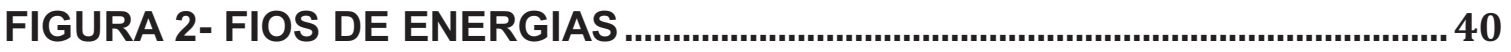

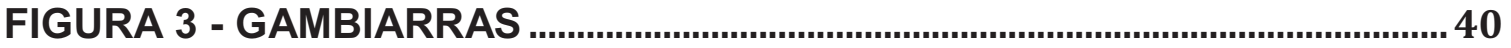

FIGURA 4 - FORMAÇÃO DE ESTALACTITES ……..............................................40

FIGURA 5 - INFILTRAÇÃO NA TUBULAÇÃO ....................................................... 40

FIGURA 6- RACHADURAS NO PISO ............................................................

FIGURA 7 - MESAS INAPROPRIADAS ..............................................................40

FIGURA 8 - CADEIRA RASGADA ......................................................................40

FIGURA 9 - CADEIRA ANTIGA ...................................................................... 40

FIGURA 10 - TRITURADOR DE PAPEL DANIFICADO ...........................................41

FIGURA 11 - BEBEDOURO SEM MANUTENÇÃO ...............................................41

FIGURA 12 - AR CONDICIONADO EM CONDIÇÕES PRECÁRIAS.....................41

FIGURA 13 - ESPAÇO REDUZIDO ……....................................................................41

FIGURA 14 - POUCO ESPAÇO O QUE POSSIBILITA TROPEÇOS....................41

FIGURA 15 - FALTA DE SABONETE E PAPEL ...................................................41

FIGURA 16 - BANHEIRO SEM PORTA …............................................................ 41

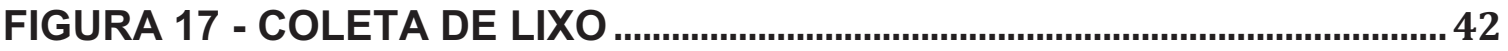

FIGURA 18 - FEZES DE RATOS E BARATAS ……..............................................42 
FIGURA 19 - FALTA DE ARQUIVOS

FIGURA 20 - ARMÁRIOS LOTADOS

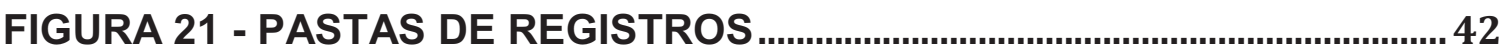

FIGURA 22 - GRADES QUEBRADAS ........................................................................ 42

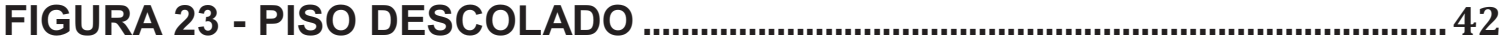

FIGURA 24 - GRADES ENFERRUJADAS …............................................................. 42 


\section{LISTA DE TABELAS}

Tabela 1 - Contexto de Produção de Bens e Serviços - CPBS:

Tabela 2 - Categorias conceituais de Qualidade de Vida no Trabalho QVT

Tabela 3 - Principais fontes de mal-estar apontadas pelo grupo focal da unidade sede

Tabela 4 - Principais fontes de mal-estar apontadas pelo grupo focal dos postos descentralizados.

Tabela 5 - Principais fontes de mal-estar em comum apontadas pelos 2 grupos focais

Tabela 6 - Fatores que Influenciam as Vivências de Mal-estar no Contexto de Produção de Serviços da Unidade Administrativa do Serviço Público Federal pesquisada. 
RESUMO

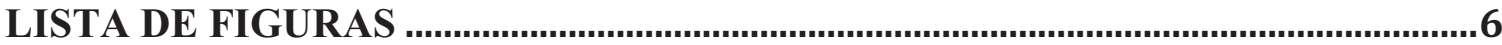

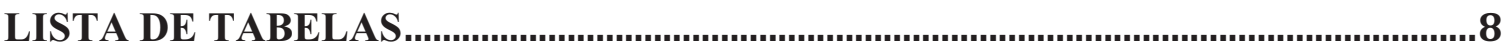

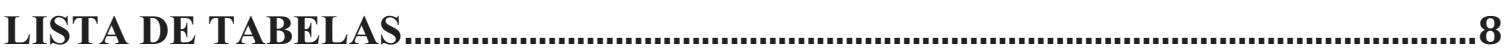

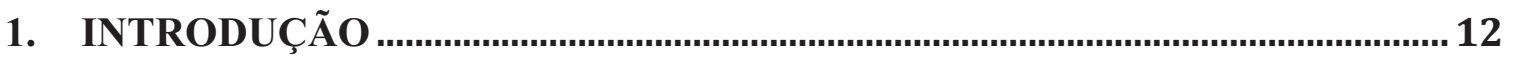

1.1. Organizaçã

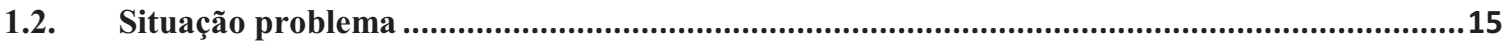

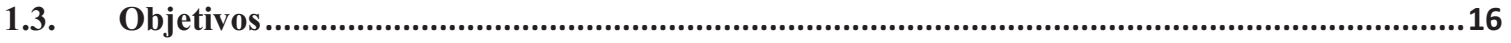

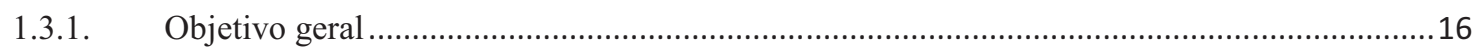

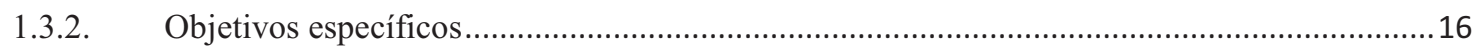

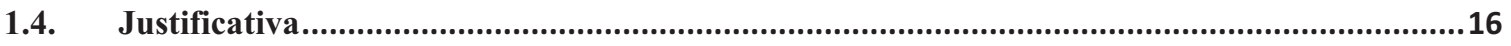

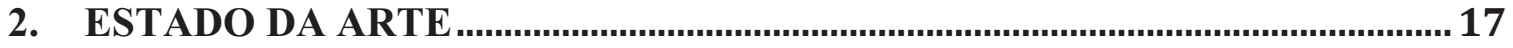

2.1. Problemas indicadores relacionados ao mal-estar no trabalho ........................................17

2.2. Problemas indicadores relacionados às estratégias de mediação...........................................18

2.3. Problemas indicadores relacionados à Qualidade de Vida no Trabalho (QVT) ....................22

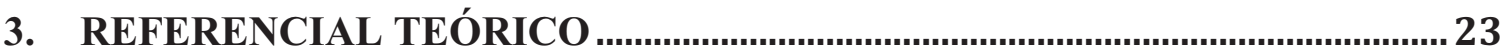

3.1. Ergonomia da atividade aplicada à Qualidade de Vida no Trabalho (QVT) .......................23

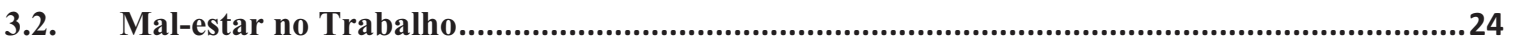

3.3. Estratégias de Mediação Individual e Coletiva (EMIC) .................................................25

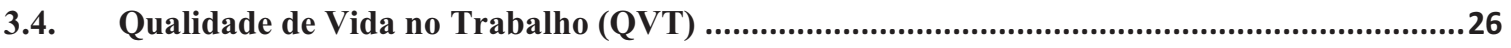

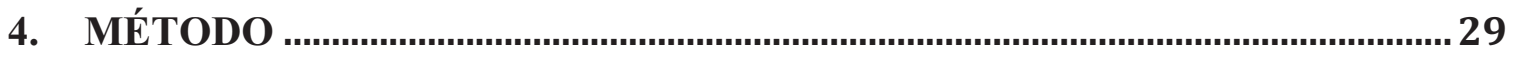

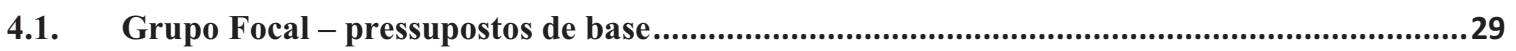

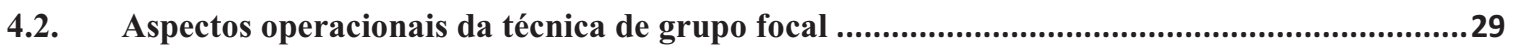

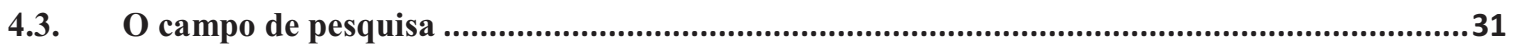




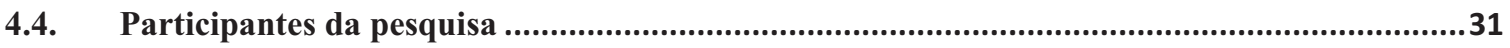

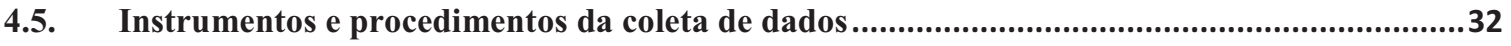

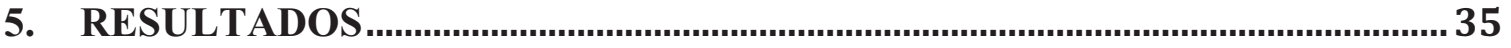

5.1. Vivências de mal-estar na administração pública pesquisada do serviço público federal: ......37

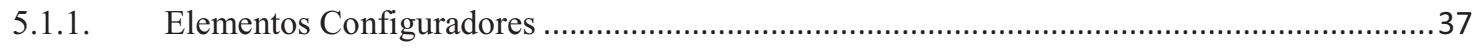

5.2. Condições de trabalho na unidade administrativa do serviço público pesquisada...................38

5.3. Estratégia de Mediação Individual e Coletiva (EMIC) da unidade administrativa do serviço público federal pesquisado ..........................................................................................................42

5.4. Organização do trabalho na unidade administrativa do serviço público pesquisada .............43

5.5. Relações socioprofissionais na unidade administrativa do serviço público pesquisada ...........44

6. CONCLUSÃO

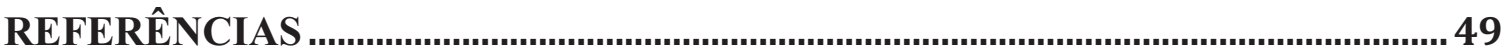




\section{Introdução}

Espaço físico inadequado, carência de material de expediente e equipamentos tecnológicos, baixos salários, descomprometimento com o trabalho, centralização de informações relacionadas à rotina de trabalho, inexistência de treinamento para desempenhar tarefas. Todas essas são queixas relativas de uma unidade administrativa do serviço público federal que serviram de ponto de partida para a realização desta pesquisa, que teve como objetivo geral identificar as fontes de mal-estar numa unidade administrativa do serviço público federal e elencar as estratégias de mediação que possam gerar qualidade de vida neste ambiente de trabalho.

Para tal estudo foi escolhida uma unidade administrativa do serviço público federal que tem como finalidade principal prestar assistência aos usuários internos e externos, principalmente, por meio da emissão de documentos e do fornecimento de informações administrativas. Para operacionalizar tal finalidade, a unidade administrativa utiliza uma estrutura administrativa do tipo vertical e com um efetivo de 85 servidores e funcionários terceirizados.

A análise documental mostra um ritmo de crescimento progressivo de usuários que procuram ser atendidos por esta unidade administrativa e, conseqüentemente existe o aumento considerável da carga de trabalho, não havendo paralelamente ou igualmente a contratação de novos funcionários e compras de novos equipamentos tecnológicos para suprir a crescente demanda de serviços.

Este trabalho busca abordar a relação entre as atividades de trabalho e as vivências de mal-estar de servidores que trabalham em um contexto de atendimento ao público. Tem como finalidade identificar os desafios e perspectivas que influenciam na Qualidade de Vida no Trabalho (QVT) desses servidores.

Segundo Ferreira \& Mendes (2003), as vivências de mal-estar dizem respeito às representações mentais dos trabalhadores relativas ao seu estado geral em determinadas situações e contextos. As vivências de mal-estar no trabalho estão relacionadas ao novo processo de reestruturação produtiva, no 
qual necessita de trabalhadores mais flexíveis e que atendam as novas necessidades trabalhistas.

Segundo Ferreira (2008) os contornos, conseqüências e tendências desses processos de mudanças começam a se esboçar e são incertos os rumos da reestruturação produtiva para o mundo do trabalho. Condições inadequadas de trabalho, desperdício de material e despreparo profissional, podem impactar na eficácia e eficiência do processo produtivo o que faz gerar insatisfação para os trabalhadores e usuários em relação a determinado produto e/ou serviço.

A influência de diferentes variáveis (condições de trabalho, organização do trabalho e relações socioprofissionais) são fatores que potencializam as vivências de mal-estar no trabalho Ferreira \& Mendes (2001). Dependendo das circunstâncias o predomínio de alguma dessas variáveis pode ocorrer para representar determinado Contexto de Produção de Bens e Serviços (CPBS), isto não implica em uma concepção desintegrada dessas dimensões. Ao contrario, essas características, do ponto de vista dinâmico, são interdependentes e estão permanente articuladas. Conforme define Ferreira \& Mendes (2003) o contexto de produção de bens e serviços (CPBS) expressa o “(...) lócus material, social e organizacional no qual se operam a atividade de trabalho e as Estratégias de Mediação Individual e Coletiva (EMIC), utilizadas pelos trabalhadores na interação com a realidade de trabalho (...)".

Segundo Rodrigues (1999), a Qualidade de Vida no Trabalho (QVT) busca eliminar ou reduzir o sentimento de mal-estar, levando o trabalhador a se sentir satisfeito no desempenho de suas tarefas diárias em seu ambiente de trabalho. A Qualidade de Vida no Trabalho (QVT) é de fundamental importância para a prevenção dos problemas organizacionais, e deve ser usada como programa contínuo na solução dos problemas, buscando melhorar as condições de trabalho e suas relações sócio-profissionais, com o engajamento dos trabalhadores e participação desses na concepção, implantação, avaliação e replanejamento, podendo ser encontradas as causas de mal-estar no trabalho.

Para lidar com essa problemática, adotou-se o modelo teórico com fundamentos na Ergonomia da Atividade. Esta tem uma abordagem cientifica que investiga a relação entre indivíduos e o Contexto de Produção de Bens e Serviços (CPBS). Segundo Ferreira \& Mendes (2003) o Contexto de Produção de Bens e Serviços (CPBS) é usado para analisar as contradições existentes na 
relação entre os sujeitos e o trabalho, de forma a gerar conhecimento cientifico em que contribui positivamente como Estratégia de Mediação Individual e Coletiva (EMIC). Sua interferência se dá no modo pelo qual os trabalhadores interagem com o ambiente de trabalho, com o social e consigo mesmo.

Desse modo, este estudo tem os seguintes objetivos específicos:

$\checkmark$ Identificar os elementos que produzem vivências de mal-estar no trabalho nesta unidade administrativa;

$\checkmark$ Sistematizar e sugerir planos de ação que possam funcionar como soluções a longo prazo para se evitar o mal-estar no trabalho;

$\checkmark$ Evidenciar os desafios que se opõem à promoção da Qualidade de Vida no Trabalho (QVT).

Para responder a essas questões e atingir os objetivos propostos, este trabalho está estruturado em três capítulos interdependentes.

O segundo e terceiro capítulos apresentam o quadro teórico para investigação do objeto de estudo. Nele, apresentam-se os estudos mais recentes relacionados aos problemas indicadores das fontes de mal-estar no trabalho, as Estratégias de Mediação Individual e Coletiva (EMIC) e Qualidade de Vida no Trabalho (QVT), também é apresentado a revisão da literatura sobre os conceitos em Ergonomia da Atividade, mal-estar no trabalho, Estratégias de Mediação Individual e Coletiva (EMIC) e Qualidade de Vida no Trabalho (QVT).

O quarto capítulo descreve o trajeto metodológico seguido para o alcance dos objetivos da pesquisa. Apresentam-se os pressupostos de base da técnica de Grupo Focal e seus aspectos operacionais, bem como os instrumentos e procedimentos adotados para coleta, tratamento e análise dos dados.

No quinto capítulo, os resultados estão sistematizados de acordo com as questões deste estudo e, concomitantemente, é feita a discussão dessas questões à luz da literatura e no enfoque teórico adotado. Na conclusão, retomase o objetivo e as questões norteadoras deste estudo, articulado-os com os principais resultados encontrados. 


\subsection{Organização}

A unidade administrativa do serviço público federal que será objeto de estudo neste trabalho tem estimulado ao longo dos últimos anos o planejamento de seus órgãos como um instrumento de gestão indispensável à atualização de suas estruturas e das unidades que a integram e dando apoio aos gestores na elaboração de suas propostas de trabalho.

Tomando por base a missão Institucional, que é produzir, integrar e divulgar conhecimento, formando cidadãos comprometidos com a ética, a responsabilidade social e o desenvolvimento sustentável, define-se que a missão desta unidade administrativa, por ser uma unidade pertencente a um "todo", deve está alinhada à razão de ser da instituição da qual faz parte, auxiliando na melhoria da qualidade de vida de toda a comunidade interna e da comunidade externa.

Atualmente essa unidade possui um quadro de 85 (oitenta e cinco) colaboradores, divididos entre servidores públicos federais, funcionários terceirizados e estagiários, distribuídos na unidade sede e em seus 12 (doze) postos de atendimento descentralizado, em que todos respondem pelos serviços de atendimento ao público interno e externo.

\subsection{Situação problema}

O sentimento de mal-estar no trabalho é a "porta de entrada" para a investigação da falta de Qualidade de Vida no Trabalho (QVT). Nesse contexto é que se manifestam as dificuldades e obstáculos das situações vivenciadas pelos trabalhadores, que geram insatisfação, aborrecimento, absenteísmo, fadiga etc. Fazer com que o ambiente onde ocorrem essas situações passe por transformações que promovam a Qualidade de Vida no Trabalho traduz-se em um desafio para os servidores e funcionários terceirizados desta unidade administrativa pesquisada.

Como então elencar as principais fontes de mal-estar que influenciam a Qualidade de Vida no Trabalho?

A problemática situa-se em não somente investigar as causas de malestar no trabalho, mas também levantar os desafios e perspectivas 
característicos existentes nesse ambiente de trabalho. Além disso, pretende-se evidenciar de que forma a Qualidade de Vida no Trabalho (QVT) passa a ser estratégia de mediação para enfrentar os desafios e perspectivas investigados.

\subsection{Objetivos}

\subsubsection{Objetivo geral}

Investigar a relação entre as fontes de mal-estar numa unidade administrativa do serviço público federal e as estratégias de mediação que possibilitam gerar qualidade de vida neste ambiente de trabalho.

\subsubsection{Objetivos específicos}

$\checkmark$ Investigar os elementos que produzem vivências de mal-estar no trabalho nesta unidade administrativa;

$\checkmark$ Sistematizar e sugerir planos de ação que possam funcionar como soluções a longo prazo para se evitar o mal-estar no trabalho;

$\checkmark$ Evidenciar os desafios que se opõem à promoção da qualidade de vida no trabalho.

\subsection{Justificativa}

Esse estudo foi elaborado com base em uma indagação com o propósito de se averiguar como os trabalhadores de uma unidade administrativa do serviço público federal identificam as principais fontes de mal-estar no trabalho, as principais conseqüências causadas pelas fontes de mal-estar, o modo de lidar com essas conseqüências e sugestões para melhorar o ambiente de trabalho para se ter Qualidade de Vida no Trabalho (QVT).

O propósito deste estudo é Identificar por meio de pesquisas bibliográficas as fontes de mal-estar no trabalho e as estratégias de mediação para a Qualidade de Vida no Trabalho (QVT). A pesquisa que foi levantada nesta unidade administrativa do serviço público federal é de fundamental importância, pois o resultado obtido na pesquisa contextualizará o cenário 
vivenciado por esses trabalhadores, o que poderá levantar ações por parte da instituição para a eliminação ou redução dos problemas existentes.

\section{Estado da arte}

\subsection{Problemas indicadores relacionados ao mal-estar no trabalho}

O cenário contemporâneo do mundo do trabalho, marcadamente em ebulição, no qual se instaurou um processo de reestruturação produtiva que inclui formas diferenciadas de se produzir e organizar o trabalho busca harmonizar (compatibilizar) mudanças, principalmente, nos âmbitos do perfil das organizações produtivas. Esse processo de transição para um novo paradigma produtivo tem sido marcado por diferentes experiências, medidas e enfoques Mattoso (1995). Esse fenômeno consiste na automação e informatização do processo de produção de mercadorias e de serviços, no qual se tem produzido mudanças estruturais profundas nas organizações por meio do estabelecimento de novas normas jurídicas, papéis e atribuições aos seus membros e diferenciados estilos gerenciais que reiteram o papel coadjuvante dos trabalhadores nos processos produtivos.

Nesse cenário de metamorfoses, o processo de reestruturação produtiva necessita de um novo perfil dos trabalhadores, ou seja, trabalhadores mais flexíveis e que atendam as novas necessidades trabalhistas. Segundo Ferreira (2008) os contornos, conseqüências e tendências desses processos de mudanças começam a se esboçar e são incertos os rumos da reestruturação produtiva para o mundo do trabalho. Com base nesse cenário, um conjunto de indicadores críticos tem sido produzido no âmbito das organizações, pois o modelo de gestão taylorista-fordista ainda prevalece como modelo de gestão organizacional e do trabalho, prejudicando o processo de reestruturação produtiva em algumas organizações.

Conforme afirma Ferreira (2008), esses indicadores se constituem numa espécie de ponta de iceberg, posto que tais indicadores críticos são ilustrativos dos dilemas contemporâneos da produção e suas causas e efeitos permanecem pouco conhecidos e estudados.

Condições inadequadas de trabalho, desperdício de material e 
despreparo profissional, podem impactar na eficácia e eficiência do processo produtivo, o que compromete a qualidade dos serviços e produtos, aumentando os custos de produção e o valor final da mercadoria, acarretando insatisfação para os trabalhadores e usuários em relação a determinado produto e/ou serviço.

Segundo Ferreira (2008, p. 83-99), quando os problemas ligados à produção "(...) tornam-se uma banalidade nas organizações, inexoravelmente eles vêm acompanhados da manifestação de uma série de indicadores críticos relacionados ás conseqüências produzidas sobre os trabalhadores (...)", tais quais, acidentes de trabalho, doenças do trabalho e o absenteísmo crônico, acarretando o afastamento laboral, o que para alguns trabalhadores funciona como estratégia de mediação para preservar a própria saúde mental e física, agravando as condições daqueles que permanecem trabalhando em virtude do aumento da carga de trabalho.

Os indicadores críticos mais recorrentes entre os usuários e consumidores se manifestam sobre a forma de queixas e reclamações da qualidade de serviços e produtos, um exemplo é a forma de tratamento recebida no contexto de atendimento. Conforme Ferreira (2008, p. 83-99) "(...) tais indicadores colocam em risco o exercício efetivo da cidadania e, em conseqüência, fragilizam os valores sociais (...)". Os problemas indicadores ligados à produção causam impacto nos trabalhadores e conseqüentemente sobre os usuários e consumidores que necessitam desses serviços e ou produtos, potencializando assim, o sentimento de mal-estar no ambiente de trabalho.

\subsection{Problemas indicadores relacionados às estratégias de mediação}

Alguns estudos demonstram que quando as condições de trabalho e a organização do trabalho são fontes de problemas, as relações socioprofissionais de trabalho desempenham um papel compensador para minimizar as fontes de mal-estar no trabalho. (FERREIRA \& MENDES, 2001).

Segundo Ferreira (2000, p. 6), esses estudos são fundamentais para a Ergonomia da Atividade, pois fornecem uma ferramenta teórica de fácil aplicação no diagnóstico ergonômico. Contudo, verifica-se que algumas imprecisões 
conceituais nas ciências do trabalho de termos como: condições de trabalho, organização do trabalho e relações socioprofissionais, “(...) ora se reportam a aspectos micro ou específicos (ex. posto de trabalho ou relações hierárquicas de comando), ora dizem respeito aos aspectos macro ou gerais (ex. condições instrumentais de trabalho e relações sociais de trabalho) (...)", (FERREIRA \& MENDES, 2003).

Para tanto, visando propor uma categoria conceitual mais ampla se propõe a articulação e síntese dessas categorias, no qual se denomina Contexto de Produção de Bens e Serviços (CPBS). Conforme define Ferreira \& Mendes, (2003), o contexto de produção de bens e serviços (CPBS) expressa o “(...) lócus material, social e organizacional no qual se operam a atividade de trabalho e as estratégias de mediação individual e coletiva, utilizadas pelos trabalhadores na interação com a realidade de trabalho (...)".

Todavia, dependendo das circunstâncias, o predomínio de alguma dessas características pode ocorrer para representar determinado contexto de produção de bens e serviços Ferreira \& Mendes (2003), isto não implica em uma concepção desintegrada dessas dimensões. Ao contrario, essas características, do ponto de vista dinâmico, são interdependentes e estão permanentemente articuladas. No enfoque teórico tridimensional (interação sujeito-atividademundo), essa noção de contexto de produção de bens e serviços, expressa o cenário da atividade de trabalho, é neste cenário que as estratégias de mediação passam a integrar o ambiente de trabalho. (FERREIRA, 2002).

O contexto de produção de bens e serviço abrange três dimensões, conforme demonstra a tabela 1 :

\begin{tabular}{|c|c|c|}
\hline \multicolumn{3}{|c|}{ Tabela 1 - Contexto de Produção de Bens e Serviços (CPBS): } \\
\hline Dimensão & Conceitos & Fatores Principais \\
\hline $\begin{array}{l}\text { Organização do } \\
\text { Trabalho (OT) }\end{array}$ & $\begin{array}{l}\text { É constituída pelos elementos } \\
\text { prescritos (formal ou } \\
\text { informalmente) que expressam as } \\
\text { concepções e as práticas de } \\
\text { gestão de pessoas e do trabalho } \\
\text { presentes no lócus de produção e } \\
\text { que balizam o seu } \\
\text { funcionamento. }\end{array}$ & $\begin{array}{l}\checkmark \text { Divisão do trabalho: hierárquica, } \\
\text { técnica, social. } \\
\checkmark \text { Produtividade esperada: metas, } \\
\text { qualidade, quantidade. } \\
\checkmark \text { Regras formais: missão, normas, } \\
\text { dispositivos jurídicos, } \\
\text { procedimentos. } \\
\checkmark \text { Tempo: duração da jornada, } \\
\text { pausas e turnos. } \\
\checkmark \text { Ritmos: prazos e tipos de pressão } \\
\checkmark \text { Controles: supervisão, fiscalização }\end{array}$ \\
\hline
\end{tabular}




\begin{tabular}{|c|c|c|}
\hline & & $\begin{array}{l}\text { e disciplina. } \\
\checkmark \text { Características das tarefas: } \\
\text { natureza e conteúdo. }\end{array}$ \\
\hline Condições de & É constituída pelos elementos & $\begin{array}{l}\checkmark \text { Ambiente físico: sinalização, } \\
\text { espaço, ar, luz, temperatura, som. }\end{array}$ \\
\hline $\begin{array}{l}\text { Condições de } \\
\text { Trabalho (CT) }\end{array}$ & $\begin{array}{l}\text { É constituída pelos elementos } \\
\text { estruturais que expressam as } \\
\text { condições de trabalho presentes } \\
\text { no lócus de produção e } \\
\text { caracterizam sua infra-estrutura, } \\
\text { apoio institucional e práticas } \\
\text { administrativas. }\end{array}$ & $\begin{array}{l}\checkmark \text { Ambiente físico: sinalização, } \\
\text { espaço, ar, luz, temperatura, som. } \\
\checkmark \text { Instrumentos: ferramentas, } \\
\text { máquinas, documentação; } \\
\checkmark \text { Equipamentos: materiais } \\
\text { arquitetônicos, aparelhagem, } \\
\text { mobiliário. } \\
\checkmark \text { Matéria prima: objetos } \\
\text { materiais/simbólicos, } \\
\text { informacionais. } \\
\checkmark \text { Suporte organizacional: } \\
\text { informações, suprimentos, } \\
\text { tecnologias. } \\
\checkmark \text { Práticas de remuneração, } \\
\text { desenvolvimento de pessoal, } \\
\text { benefícios. }\end{array}$ \\
\hline $\begin{array}{l}\text { Relações Sociais } \\
\text { de Trabalho } \\
\text { (RST) }\end{array}$ & $\begin{array}{l}\text { É constituída pelos elementos } \\
\text { interacionais que expressam as } \\
\text { relações socioprofissionais de } \\
\text { trabalho, presentes no lócus de } \\
\text { produção e caracterizam sua } \\
\text { dimensão social. }\end{array}$ & $\begin{array}{l}\checkmark \text { Interações hierárquicas: chefias } \\
\text { imediatas, chefias superiores. } \\
\checkmark \text { Interações coletivas intra e inter- } \\
\text { grupos: membros da equipe de } \\
\text { trabalho; membros de outros } \\
\text { grupos de trabalho. } \\
\checkmark \text { Interações externas: usuários, } \\
\text { consumidores, representantes } \\
\text { institucionais (fiscais, } \\
\text { fornecedores). }\end{array}$ \\
\hline
\end{tabular}

Fonte: Ferreira \& Mendes (2003, p. 17-18).

Segundo Ferreira e Mendes (2003), existem três aspectos fundamentais no diagnóstico ergonômico dos indicadores críticos em Contexto de Produção de Bens e Serviços (CPBS), são eles: (a) tarefas formais e informais; (b) eventos críticos no contexto de produção; (c) complexidade no contexto de produção.

Conforme afirma Ferreira \& Mendes (2003) as tarefas podem ser definidas como a operacionalização do trabalho prescrito formal ou informalmente em termos de objetivo(s) estabelecido(s) em condições determinadas para um sujeito ou um coletivo de trabalhadores. A noção de tarefa diz respeito, principalmente, à forma de cumprimento dos deveres organizacionais em termos de: cumprimentos de metas; modos de utilização do suporte organizacional, cumprimento de prazos, obediência aos procedimentos e às regras.

$\checkmark$ É sempre preexistente ou anterior à atividade; 
$\checkmark$ Veicula explícita ou implicitamente um modelo de sujeito;

$\checkmark$ Requer do sujeito uma dupla atividade: de elaboração mental e de execução.

Para Ferreira \& Mendes (2003) os eventos críticos designam uma ruptura no curso normal de uma atividade de trabalho que pode ser uni ou multicausal (fatores técnicos, organizacionais, tecnológicos, panes, erros etc.).

$\checkmark$ Originam-se da distância do previsto nas normas, procedimentos e instruções pré-estabelecidas pela organização;

$\checkmark$ Podem ser classificados em graus distintos de gravidade;

$\checkmark$ Obrigam os trabalhadores a reestruturarem suas estratégias de trabalho para responderem adequadamente às novas exigências que se configuram.

De acordo com Ferreira \& Mendes (2003)

Complexidade é um conjunto de circunstâncias/fatos resultantes do confronto entre as especificidades do contexto de produção de bens e serviços (dificuldades extrínsecas) e o grau de expertise (competências) individual e coletivo dos trabalhadores (limites intrínsecos), que impõe um custo humano específico aos trabalhadores.

Os indicadores principais de complexidade do Contexto de Produção de Bens e Serviços são:

$\checkmark$ Do ponto de vista extrínseco: a multiplicidade de fatores, interações, evoluções dinâmicas, concomitância, variabilidade e imprevisibilidade, caráter abstrato das informações, imprecisão das tarefas, divisão precária do trabalho, situações instáveis;

$\checkmark$ Do ponto de vista intrínseco: as capacidades de assimilação e acomodação de informações provenientes das situações de trabalho, a resolução de problemas, as tomadas de decisão e, principalmente, as experiências existentes e o estado de saúde vivenciado pelos trabalhadores num dado momento. 


\subsection{Problemas indicadores relacionados à Qualidade de Vida no Trabalho (QVT)}

Segundo Rodrigues (1999), a Qualidade de Vida no Trabalho (QVT) busca eliminar ou reduzir o sentimento de mal-estar, levando o trabalhador a se sentir satisfeito no desempenho de suas tarefas diárias em seu ambiente de trabalho. Com a constante mudança no mundo do trabalho, por meio das novas formas gerenciais, do mundo cada vez mais globalizado, da inserção de novas tecnologias e a demasiada especialização do trabalho, exige-se que os trabalhadores entrem no ritmo exigido pelas organizações para não se tornarem profissionais desinformados ou até mesmo com conhecimentos obsoletos.

Todas essas transformações, que nos dias atuais ocorrem de forma bastante rápida, desenvolvem o sentimento de mal-estar pelos trabalhadores, pois as atividades desempenhadas por esses indivíduos não são aprimoradas ou concretizadas de forma satisfatória, isso porque todas essas mudanças desenvolvem sentimentos como fadiga, absenteísmo, insatisfação etc, e como conseqüência a própria organização também sofre com o resultado do trabalho que por ventura venha ser produzido com a insatisfação.

Segundo Ferreira \& Mendes (2004), a implementação de um programa de Qualidade de Vida no Trabalho (QVT) de natureza preventiva precisa atuar nas causas reais dos problemas no contexto de trabalho que se caracterizam, basicamente, pela presença de três tipos de problemas: as condições de trabalho, as regras que orientam a execução da tarefa e as relações sociais de trabalho, todas estas representam fontes de conflitos freqüentes no ambiente de trabalho.

Sendo assim, o ambiente organizacional, além de priorizar seus objetivos organizacionais, deve também ser fonte de oportunidades, de objetivos, de necessidades pessoais satisfatórias e motivacionais para os trabalhadores. Segundo Fernandes (1996), o desenvolvimento das metas organizacionais apenas terá êxito se as necessidades dos indivíduos e suas capacidades forem desenvolvidas ou aprimoradas.

Assim, na promoção da Qualidade de Vida no Trabalho (QVT), os fatores motivacionais e de satisfação são críticos e devem ser observados na estratégia 
de mediação que lidará com os desafios gerados pelo sentimento de mal-estar no trabalho.

\section{Referencial teórico}

\subsection{Ergonomia da atividade aplicada à Qualidade de Vida no Trabalho (QVT)}

Existem diversos motivos para abordar as possibilidades de "diálogos e perspectivas" entre Ergonomia da Atividade e Qualidade de Vida no Trabalho (QVT), segundo Ferreira (2008), do ponto de vista social, as metamorfoses que operam no trabalho e suas implicações econômicas, políticas, tecnológicas e culturais exercem papel relevante na vida em sociedade (dirigentes, gestores, trabalhadores e usuários/clientes), desafiando a relação de bem-estar de quem trabalha e a satisfação de usuários/clientes com os imperativos de eficiência e eficácia nos contextos de produção de mercadorias e serviços. Assim, a ergonomia tem contribuído para a melhoria dos contextos de trabalho e a Qualidade de Vida no Trabalho (QVT) se configura como uma necessidade para eliminar ou atenuar os indicadores críticos existentes nestes cenários.

Do ponto de vista das organizações, a relevância esta relacionada aos problemas presentes no cotidiano dos ambientes de trabalho. Para Ferreira (2008), no âmbito do serviço público a qualidade dos serviços prestados pelas agências governamentais e por seus dirigentes são decorrentes do fortalecimento dos regimes democráticos e a postura mais vigilante e reivindicatória dos cidadãos-usuários o que faz com que as organizações busquem a Qualidade de Vida no Trabalho (QVT) como forma de atenuar/solucionar os problemas existentes nos ambientes de trabalho.

Do ponto de vista acadêmico, a intervenção da Ergonomia da Atividade na inter-relação indivíduo-contexto de trabalho é de viés preventivo, seu diagnóstico busca mapear sintomas de disfuncionamentos e prescrever recomendações para o reequilíbrio satisfatório no ambiente de trabalho, agregando assim qualidade de vida para esses trabalhadores.

Dessa forma, a Ergonomia da Atividade contribui na gestão de Recursos humanos das organizações e na implementação de melhorias, pois, segundo lida (2000), "A ergonomia é o estudo da adaptação do trabalho ao homem", ou 
seja, através do estudo do relacionamento do ser humano com o seu trabalho, relacionando a utilização de máquinas e equipamentos, características fisiológicas, psicológicas, a ergonomia passa a ser uma opção viável para incrementar a Qualidade de Vida no Trabalho (QVT) e, conseqüentemente, a qualidade do processo produtivo, por meio de melhorias no ambiente de trabalho, interação homem-máquina, fatores de segurança, dentre outros.

\subsection{Mal-estar no Trabalho}

De acordo com Ferreira \& Seidl (2009), mal-estar é um fenômeno que coabita o mundo do trabalho, do pondo de vista empírico é um dado comum na literatura das ciências do trabalho, alguns estudos mostram uma adversidade de indicadores nesta temática, também aparece em resultados de pesquisas (Diniz, 2006; Veras, 2006). Contudo, o conceito relacionado ao mal-estar no trabalho é bastante escasso em estudos e pesquisas.

Segundo Ferreira \& Mendes (2003), as vivências de mal-estar diz respeito às representações mentais dos trabalhadores relativas ao seu estado geral em determinadas situações e contextos. As representações de mal-estar são constituídas de avaliações negativas que os trabalhadores fazem sobre o seu estado físico, psicológico e social relativo ao contexto no qual estão inseridos, são características das vivências de mal-estar:

$\checkmark$ conteúdo das representações referentes ás conseqüências individuais e coletivas do custo humano do trabalho;

$\checkmark$ A formação resultante do confronto entre exigências afetivas, cognitivas e físicas inerentes aos contextos de produção e às estratégias de mediação dos trabalhadores;

$\checkmark$ A configuração resultante da eficiência e da eficácia das estratégias de mediação individuais e coletivas dos trabalhadores para amenizar o predomínio do sentimento de mal-estar no trabalho.

A influência de diferentes variáveis (suporte organizacional, relações socioprofissionais e processos de trabalho) são fatores que potencializam as vivências de mal-estar no trabalho (Ferreira \& Mendes, 2001). Baixos níveis de bem-estar podem contribuir para a origem de problemas como a rotatividade e absenteísmo, além de trazerem custos para a organização, pois aumentam a 
probabilidade de erros e contribuem para a perda de qualidade nos serviços Holman (2002). Ademais aspectos influenciam as vivências de mal-estar no contexto de trabalho são associadas à divisão e a padronização de tarefas com subutilização da criatividade e do potencial técnico dos atendentes; rigidez hierárquica, com excesso de procedimentos burocráticos, centralização das informações e falta de participação nas decisões; pouca perspectiva de crescimento profissional; falta de reconhecimento; sentimento de injustiça; de ingratidão da instituição (pois as recompensas não consideram as competências); tédio por desempenhar tarefas pouco valorizadas (FERREIRA, 2002).

\subsection{Estratégias de Mediação Individual e Coletiva (EMIC)}

Para Ferreira \& Mendes (2003) as estratégias de mediação individual e coletiva (EMIC) referem-se aos modos de pensar, sentir e agir individual e coletivo dos trabalhadores para enfrentar as contradições presentes no contexto de trabalho, visando assegurar a integridade física, a psicológica e social prevalecendo assim, às vivências de bem-estar sobre as de mal-estar. Existem três tipos principais de estratégias de mediação individual e coletiva sendo estudadas pela ergonomia apenas as "estratégias operatórias" e que servirão de base teórica neste trabalho, as "estratégias de mobilização coletiva" e "estratégias defensivas" constituem as especificidades conceituais em Psicodinâmica do Trabalho. Alguns aspectos caracterizam as estratégias operatórias:

$\checkmark$ Têm como base as experiências de trabalho dos sujeitos;

$\checkmark$ Evoluem de acordo com a auto-avaliação de indivíduos e grupos e conforme as imposições externas do contexto de produção;

$\checkmark$ As representações referentes às conseqüências individuais e coletivas com a proposta de reduzir o custo humano do trabalho e proporcionar o predomínio de vivência de bem-estar;

$\checkmark$ Viabilizam a atividade dos trabalhadores com base em representações para a sua execução (savoir-faire, golpe de vista, saberes tácitos, macetes, habilidades motoras e sensoriais). 
Para Ferreira \& Mendes (2003), essas vivências possuem caráter dinâmico resultante do confronto entre as exigências: (a) físicas sob a forma de dispêndio fisiológico e biomecânico, (b) cognitivas sob a forma de dispêndio mental e, (c) afetivas sob a forma de dispêndio emocional, no qual suas representações tomam forma em determinados contextos do ambiente de trabalho.

Dessa forma, os trabalhadores utilizam suas estratégias de mediação para lidar com as fontes de mal-estar presentes no contexto de trabalho com o objetivo de vivenciar o bem-estar no trabalho.

\subsection{Qualidade de Vida no Trabalho (QVT)}

A contribuição feita por alguns autores acerca do conceito de Qualidade de Vida no Trabalho (QVT) possibilitam identificar quais são as suas dimensões no ambiente de trabalho, além de ser fator preponderante para melhorar o ambiente e suas relações socioprofissionais, contudo a origem dos estudos sobre Qualidade de Vida no Trabalho (QVT) é abordada na literatura de modo não consensual. As décadas de 1930 e 1940 são caracterizadas pela criação dos primeiros programas de segurança no trabalho, o propósito desses programas era mudar o ambiente de trabalho levando bem-estar aos trabalhadores, movida pela necessidade de contrapor-se a desumanização no trabalho surgida com a aplicação de métodos rigorosos. Segundo Chiavenato (1983) a Teoria das Relações Humanas com a concepção do homem social considera os trabalhadores como seres complexos, com sentimentos, desejos e temores. As pessoas são motivadas por certas necessidades e alcançam satisfação através de grupos com os quais interagem.

$\mathrm{Na}$ década de 1950, surge na Inglaterra, o primeiro modelo de QVT Rodrigues (1991) tendo por base os estudos de Eric Trist e colaboradores, seus estudos investigavam a relação individuo-trabalho-organização, com base na reestruturação da tarefa, com o objetivo de tornar a vida dos trabalhadores menos penosa (FERNANDES, 1996).

Conforme França (1997:80):

Qualidade de vida no trabalho (QVT) é o conjunto das ações de uma empresa que envolvem a implantação de melhorias e inovações gerenciais e tecnológicas no ambiente de trabalho. A construção da 
qualidade de vida no trabalho ocorre a partir do momento em que se olha a empresa e as pessoas como um todo, o que chamamos de enfoque biopsicossocial. O posicionamento biopsicossocial representa o fator diferencial para a realização de diagnóstico, campanhas, criação de serviços e implantação de projetos voltados para a preservação e desenvolvimento das pessoas, durante o trabalho na empresa.

Consideram Tolfo \& Piccinini (2002), que os estudos sobre Qualidade de Vida no Trabalho (QVT) deram inicio na década de 1960, a fim de minimizar os efeitos negativos e trazer bem-estar para o trabalho, por meio do movimento de conscientização da importância de se buscarem melhores formas de organizar o trabalho.

Na década de 1970, é publicado o clássico estudo de Walton (1973), que conforme afirma Ferreira (2006b) é um dos modelos mais citados na literatura, no qual define que a Qualidade de Vida no Trabalho (QVT) é depende de oito fatores, conforme tabela abaixo:

Tabela 2 - Categorias conceituais de Qualidade de Vida no Trabalho - QVT

\begin{tabular}{|l|l|}
\hline CRITÉRIOS & INDICADORES DE QVT \\
\hline Compensação justa e adequada & $\begin{array}{l}\text { Equidade interna e externa } \\
\text { Justiça na compensação } \\
\text { Partilha de ganhos de produtividade }\end{array}$ \\
\hline Condições de trabalho & Jornada de trabalho razoável \\
& Ambiente físico seguro e saudável \\
& Ausência de insalubridade \\
\hline Uso e desenvolvimento de capacidades & $\begin{array}{l}\text { Autonomia } \\
\text { Autocontrole relativo }\end{array}$ \\
& Qualidades múltiplas \\
& Informações sobre o processo total do trabalho \\
\hline Oportunidade de crescimento e segurança & $\begin{array}{l}\text { Possibilidades de carreira } \\
\text { Crescimento pessoal }\end{array}$ \\
& $\begin{array}{l}\text { Perspectiva de avanço salarial } \\
\text { Segurança de emprego }\end{array}$ \\
\hline Integração social na organização & Ausência de preconceitos \\
& Igualdade \\
& Mobilidade \\
& Relacionamento \\
& Senso Comunitário \\
\hline Constitucionalismo & Direitos de proteção ao trabalhador \\
& Privacidade pessoal \\
& Liberdade de expressão \\
& Tratamento imparcial \\
& Direitos trabalhistas \\
\hline Relevância social do trabalho na vida & INDICADORES DE QVT \\
\hline ORITÉRIOS & Geográficas \\
& Papel balanceado no trabalho \\
& Estabilidade de horários \\
& Poucas mudanças geográficas \\
& Tempo para lazer da família \\
\hline & $\begin{array}{l}\text { Imagem da empresa } \\
\text { Responsabilidade social da empresa } \\
\text { Responsabilidade pelos produtos }\end{array}$ \\
\hline & \\
\hline
\end{tabular}


Fonte: Walton apud (Fernandes 1996:48).

Segundo Ferreira (2006b) define que a Qualidade de Vida no Trabalho (QVT) sob duas perspectivas diferentes: a) sob a ótica da gestão organizacional no âmbito das condições, da organização e das relações socioprofissionais de trabalho, no qual esta se apresenta por um conjunto de normas, diretrizes e práticas e tem como objetivo alcançar o desenvolvimento e o bem-estar pessoal e coletivo para o alcance da promoção do exercício da cidadania organizacional no ambiente de trabalho; b) sob a ótica dos sujeitos, no qual o Contexto de Produção de Bens e Serviços (CPBS) em que estão inseridos, "(...) indicando as fontes de bem-estar no trabalho, de reconhecimento institucional e coletivo, de possibilidades de crescimento profissional e de respeito às características individuais (...)".

Segundo Cardoso \& Stano (2005) o conceito de qualidade de vida engloba "(...) além, dos atos legislativos que protegem 0 trabalhador, 0 atendimento das necessidades e aspirações humanas, calcado na idéia de humanização do trabalho e nas responsabilidades sociais da empresa (...)".

Para Sucesso (1998), a qualidade de vida abrange: renda capaz de satisfazer às expectativas pessoais e sociais, orgulho pelo trabalho realizado, vida emocional satisfatória, auto-estima, imagem da empresa/instituição junto à opinião pública, equilíbrio entre trabalho e lazer, horários e condições de trabalho sensato, oportunidades e perspectivas de carreira, possibilidade de uso do potencial, respeito aos direitos e, justiça nas recompensas.

De forma geral, os conceitos de Qualidade de Vida no Trabalho (QVT) são focados nas ações individuais e coletivas dos trabalhadores, com vistas ao alcance de um Contexto de Produção de Bens e Serviços (CPBS), no qual as condições, a organização e as relações sociais de trabalho contribuem para a prevalência do bem-estar de quem trabalha (FERREIRA \& MENDES, 2004). 


\section{Método}

Este capítulo apresenta a abordagem metodológica adotada e a pertinência desta para a investigação das fontes de mal-estar no trabalho em uma unidade administrativa do serviço público federal. Num primeiro momento, são descritos os pressupostos teóricos de base do método, em seguida, detalhase o campo em que foi realizada a pesquisa, bem como os participantes, os instrumentos e os procedimentos utilizados durante a coleta de dados. Por fim, apresentam-se os métodos de análise qualitativa dos dados.

\subsection{Grupo Focal - pressupostos de base}

O enfoque metodológico utilizado na presente pesquisa apóia-se na técnica de Grupo Focal, conforme afirma lervolino e Pelicone (2001), o principal objetivo do grupo focal consiste na interação entre os participantes e o pesquisador e a coleta de dados, por meio de discussão com foco, em tópicos específicos e diretivos (por isso é chamado de grupo focal).

De acordo com Debus (1997), o grupo focal em seu caráter subjetivo de investigação é utilizado como estratégia metodológica qualitativa, já que a pesquisa qualitativa caracteriza-se por buscar respostas acerca do que as pessoas pensam e sentem sobre determinado assunto.

Alguns requisitos importantes da técnica de grupo focal são: a escolha dos participantes, do moderador, do observador, da elaboração do tema, e do local dos encontros, estes são fundamentais para a organização e sistematização de uma investigação por meio da técnica de grupo focal.

\subsection{Aspectos operacionais da técnica de grupo focal}

Primeiramente, é preciso definir claramente o tema, de acordo com Meier e Kudlowiez (2003), é de extrema importância a elaboração do mesmo para a investigação, pois este tem de estar de acordo com os objetivos da pesquisa.

Faz-se necessário sensibilizar os participantes, mostrando o real objetivo da pesquisa. Para a eficiência da aplicação da técnica de grupo focal deve-se 
esclarecer aos participantes os cuidados éticos, por parte do(s) pesquisador (es), em relação às informações obtidas por este método.

Para Ressel, Gualda e Gonzales (2002), a escolha dos participantes é associada ao objetivo da pesquisa: eles devem estar dentro do contexto a ser estudado e devem apresentar características em comum, porém a decisão de participar de um grupo focal é individual, o participante não deve se sentir obrigado ou coagido a participar desta técnica.

Para Chiesa e Ciampone (1999), o ideal é que o grupo focal tenha entre um mínimo de seis e um máximo de doze pessoas. Conforme (FOLCH- LYON E TROST, 1982):

A situação de grupo pode também encorajar participantes a revelar comportamentos e atitudes que eles poderiam não expor conscientemente em uma entrevista individual. Isso ocorre porque os participantes freqüentemente, se sentem mais confortáveis e seguros na companhia de pessoas que compartilham atitudes, comportamentos e opiniões similares ou simplesmente porque eles acabam sendo conduzidos pela discussão em curso.

O grupo focal é uma técnica de coleta de dados que não concentra sua busca apenas nas informações obtidas dos participantes. Esta baseia-se na tendência humana de formar opiniões e atitudes na interação com outros indivíduos. Nesse sentido cabe ao moderador do grupo (facilitador, pesquisador) propor questões com o intuito de provocar os participantes da pesquisa com potenciais aspectos relacionados a determinado tema que se pretenda discutir, encorajando os participantes a expressar seus sentimentos, percepções, opiniões etc., em relação ao objeto da pesquisa.

De acordo com Dall"agnol e Trench (1999), o moderador deve estar preparado para ministrar a técnica, devendo ter entusiasmo para conduzir e controlar o grupo focal, bem como obter todos os recursos necessários para a instrumentalização do processo. É dele também a tarefa de garantir que a pesquisa não seja dominada por pessoas com facilidade de falar e a opinião dos tímidos não seja expressada, para isso é importante que estes sejam alocados de forma que não se sintam excluídos ou desprestigiados pelo grupo/moderador. 
O observador é o auxiliador do moderador, ele tem o papel de "tomar nota" das principais impressões verbais e não verbais do grupo focal e as sintetizar de acordo com o que foi expresso durante a pesquisa.

O local para se aplicar a pesquisa com a técnica de grupo focal, conforme afirma Debus (1997), deve ser em um local em que os participantes se sintam à vontade, no qual o moderador possa ter a visão panorâmica de todos os participantes, de forma a obter maior controle sobre o grupo.

\subsection{O campo de pesquisa}

O contexto de trabalho onde se realizou a pesquisa trata-se de uma unidade administrativa do serviço público federal. Esta unidade administrativa é composta por uma unidade sede e por 12 postos de atendimento descentralizados, em que todos respondem pelos serviços de atendimento ao público interno e externo.

Esta unidade administrativa do serviço público federal foi escolhida por aparentar em meio a outras unidades desta mesma fundação, indícios de fontes de mal-estar para os trabalhadores que ali atuam tais quais (ambiente-físico, suporte organizacional etc.).

Diante desse cenário, surgiu o interesse em investigar as fontes de malestar no trabalho desta unidade administrativa do serviço público federal e as estratégias de mediação utilizadas por esses trabalhadores para lidar com esses problemas.

\subsection{Participantes da pesquisa}

A unidade administrativa emprega 85 (oitenta e cinco) entre servidores públicos federais e funcionários terceirizados. Por se tratar de um método no qual a decisão de participar do grupo focal é individual, os que participaram se sensibilizaram com o objetivo da pesquisa e se disponibilizaram para a realização desta. Participaram da pesquisa 14 pertencentes a unidade sede e 12 lotados nos postos descentralizados, perfazendo um total de 26 participantes sendo todos, integrantes do corpo operacional/gerencial da atividade meio estudada. 


\subsection{Instrumentos e procedimentos da coleta de dados}

A abordagem metodológica desta pesquisa apóia-se na técnica de Grupo Focal, pois é uma ferramenta que permite um conjunto de pessoas discutir e comentar um tema, que é objeto da pesquisa, com base em suas experiências pessoais.

A demanda desta pesquisa se deu por meio da observação livre do ambiente de trabalho dos servidores públicos federais e funcionários terceirizados dessa unidade administrativa do serviço público federal e pelas constantes reclamações a respeito de suas condições de trabalho.

O primeiro contato foi em uma reunião com o diretor da unidade administrativa juntamente com os pesquisadores interessados pela pesquisa, nesta reunião foram apresentados os objetivos, as metas, a abordagem metodológica e o cronograma de execução para a realização do diagnóstico do contexto de trabalho desta unidade administrativa do serviço público federal.

Após a autorização para a aplicação do diagnóstico do contexto de trabalho pelo diretor da unidade administrativa, iniciou-se o processo de sensibilização dos servidores públicos e funcionários terceirizados desta unidade administrativa do serviço público federal.

Para a etapa de sensibilização foi elaborado um folder (anexo 1), no qual constavam as informações relacionadas ao objetivo do diagnóstico do contexto de trabalho desta unidade administrativa do serviço público federal, as metas da pesquisa, local de realização do projeto, período de execução, abordagem metodológica, participantes da pesquisa, etapas do processo, instrumentos utilizados para a realização da pesquisa e a explicitação dos princípios éticos.

A sensibilização se deu em 2 momentos diferentes, haja vista que foram formados 2 grupos focais nesta unidade administrativa do serviço público federal: 1 na unidade sede, e o outro, com os 12 postos descentralizados. 0 objetivo dos pesquisadores foi de motivar e sensibilizar os servidores públicos e funcionários terceirizados desta unidade administrativa para a participação do Grupo Focal, para isto os folders explicativos (anexo 1) foram entregues aos trabalhadores e ao mesmo tempo os pesquisadores sanaram as dúvidas existentes a cerca do material distribuído. 
O preparo dos materiais e instrumentos utilizados para a realização da pesquisa foram montados e checados antecipadamente, a ambientação do local, disposição dos acentos foram estruturados para alocar os participantes de forma confortável, no qual todos pudessem ser vistos e ouvidos, buscando assim, minimizar a falta de participação de pessoas tímidas ou apenas a participação de pessoas muito falantes, como preconiza os pressupostos da técnica de Grupo Focal.

No dia da realização da pesquisa o moderador recebeu os participantes buscando criar um clima agradável e receptivo, ao se iniciar a pesquisa, as duvidas relacionadas ao folder (anexo 1) foram sanadas, após esse momento relembrou-se da questão ética sobre o sigilo dos dados por parte dos pesquisadores e dos objetivos da pesquisa.

A condução dos grupos focais se deu em um dia para cada grupo (um dia para o grupo da sede administrativa e outro dia para o grupo dos postos descentralizados), em 3 etapas diferentes: a etapa 1 individual, etapa 2 subgrupo e a etapa 3 síntese do grupo, todas essas etapas aconteceram em um único dia e em um tempo médio de 2 horas. O grupo focal da unidade sede foi composto por 14 participantes e o grupo focal dos postos descentralizados por 12 participantes.

A etapa individual para cada grupo focal teve um tempo médio de realização de 20 minutos, nesta etapa o moderador e observador distribuíram para os participantes da pesquisa um formulário (anexos 2 e 3) com 4 questões relacionadas as fontes de mal-estar no trabalho, contendo também um mini questionário para verificar o perfil dos participantes. Antes do preenchimento foram apresentados exemplos relacionados a cada questão para melhor compreensão do que deveria ser escrito nos formulários. Para cada questão a respeito das fontes de mal-estar no trabalho foi gasto um tempo médio de 5 minutos.

Ao término da etapa individual, o moderador do grupo solicitou aos participantes que se dividissem em subgrupos, iniciando assim, a segunda etapa. O grupo focal da unidade sede obteve a subdivisão de 5 grupos, sendo 4 grupos com 3 componentes, e 1grupo com 2 componentes. A subdivisão dos postos descentralizados foram compostos por 4 grupos, cada um contendo 3 participantes. 
Nesta segunda etapa o moderador da pesquisa solicitou aos participantes do subgrupo que discutissem a respeito das 4 questões sobre as fontes de mal-estar no trabalho. Nesta etapa foram distribuídos um formulário (anexo 4) para cada subgrupo, neste formulário constavam as 4 questões sobre as fontes de mal-estar no trabalho.

O moderador orientou aos participantes dos subgrupos que elegessem um relator para cada subgrupo. O relator teve a função de registrar por escrito, no formulário (anexo 4) distribuído, os pontos que foram definidos de forma consensual pelo seu subgrupo a respeito das questões sobre as fontes de Malestar no trabalho, para a conclusão desta etapa foram gastos 20 minutos.

A terceira etapa se caracterizou pela síntese do grupo, onde as discussões foram ampliadas para todos os participantes do grupo focal. Nesta etapa os relatores de cada subgrupo divulgaram, para todos os participantes, os pontos de consenso sobre as 4 questões relacionadas as fontes de mal-estar no trabalho a que seus respectivos subgrupos chegaram, para a conclusão desta etapa foram gastos 40 minutos.

Após a participação dos relatores na pesquisa, o moderador informou aos grupos que seria necessário ordenar as fontes de mal-estar no trabalho por grau de importância. Neste momento, todos os participantes discutiram e colocaram suas opiniões. Em alguns momentos, o grupo não teve um consenso a respeito da ordem de priorização ou da escrita correta das fontes de mal-estar, então o moderador interveio na discussão para equilibrar o clima e ajustar quaisquer erros.

O observador exerceu importante papel nesta última etapa, pois foi ele quem registrou a síntese das principais fontes de mal-estar no trabalho de acordo com o grau de importância, tomando sempre o cuidado de registrar a real opinião do grupo. Para este momento foram gastos aproximadamente 40 minutos.

Ao término da síntese das principais fontes de mal-estar no trabalho pelos grupos, buscou-se avaliar a técnica de grupo focal, o moderador solicitou aos participantes que indicassem os pontos positivos e os pontos negativos do grupo focal. O observador também anotou todas as indicações.

Ao final do grupo focal, o moderador e observador informaram aos participantes que com base nas informações obtidas pela pesquisa, um relatório 
de diagnóstico (anexo 5) seria criado, no qual constariam resumidamente as principais fontes de mal-estar no trabalho.

Com as informações obtidas pelos grupos focais, os pesquisadores iniciaram o processo de registro das principais fontes de mal-estar no trabalho, para isso foram registradas 205 fotografias que demonstram as fontes de malestar no trabalho, das quais 24 constam no relatório de diagnóstico.

O relatório de diagnóstico do contexto de trabalho desta unidade administrativa do serviço publico federal contém os objetivos da pesquisa, a justificativa do diagnóstico, explicita quem é a unidade administrativa que foi campo de pesquisa para este estudo, aponta a trajetória metodológica do grupo focal, os principais resultados obtidos por esta pesquisa e os registros fotográficos no qual demonstram as principais fontes de mal-estar no trabalho nesta unidade administrativa.

O relatório de diagnóstico do contexto de trabalho desta unidade administrativa foi encaminhado para todos os participantes do grupo focal, a fim de demonstrar de forma resumida todas as etapas da pesquisa. Este relatório de diagnostico do contexto desta unidade administrativa servirá de base para a análise dos dados obtidos nesta pesquisa.

\section{Resultados}

Como já mencionado, foi utilizado como abordagem metodológica a técnica de grupos focais e nesta foram propostas aos participantes 4 questões:

$\checkmark$ Quando penso no meu trabalho na unidade administrativa a principal fonte de Mal-Estar é...

$\checkmark$ A conseqüência para a fonte de Mal-Estar é...

$\checkmark$ A forma de lidar com a conseqüência apontada para a fonte de MalEstar é...

$\checkmark$ A sugestão para o problema relacionado para fonte de Mal-Estar é...

Para a primeira questão, o Grupo Focal da Unidade Sede considerou como as principais fontes de mal-estar as listadas abaixo: 


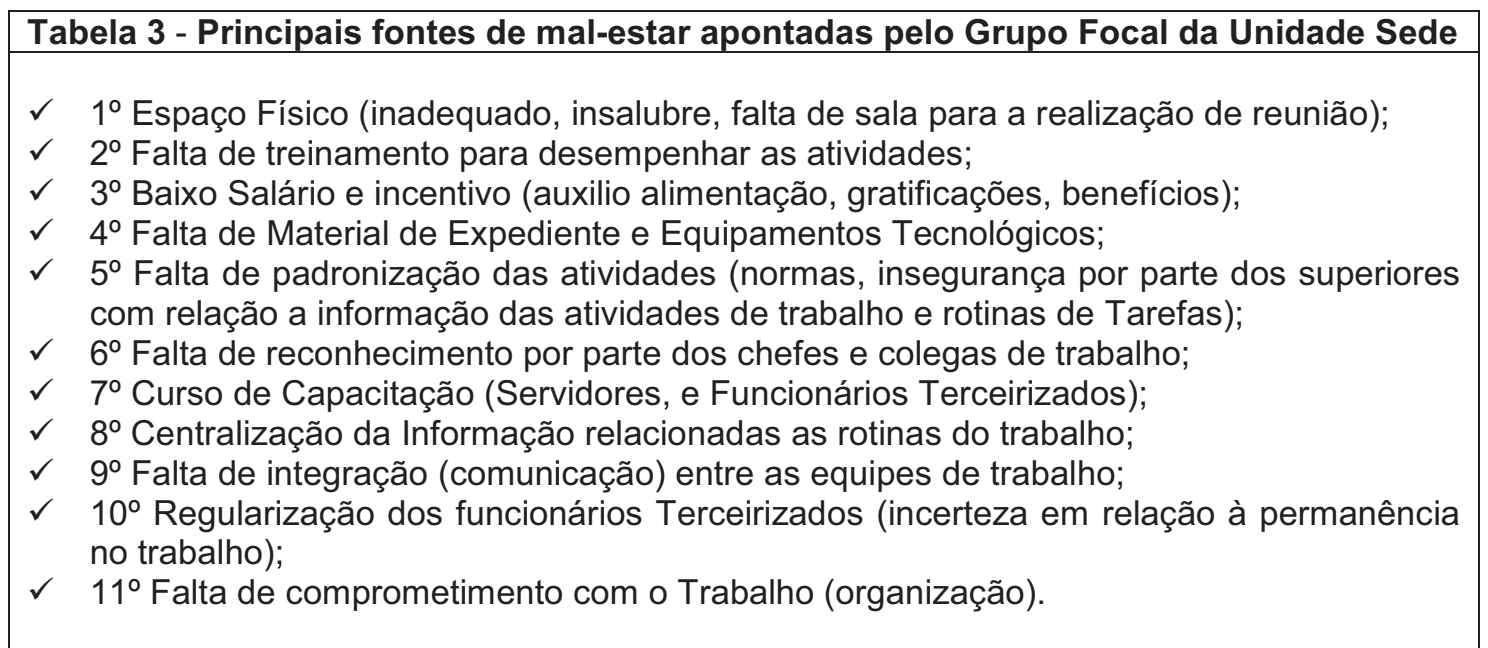

Para a primeira questão, o Grupo Focal dos Postos Descentralizados consideraram como as principais fontes de mal-estar as listadas abaixo:

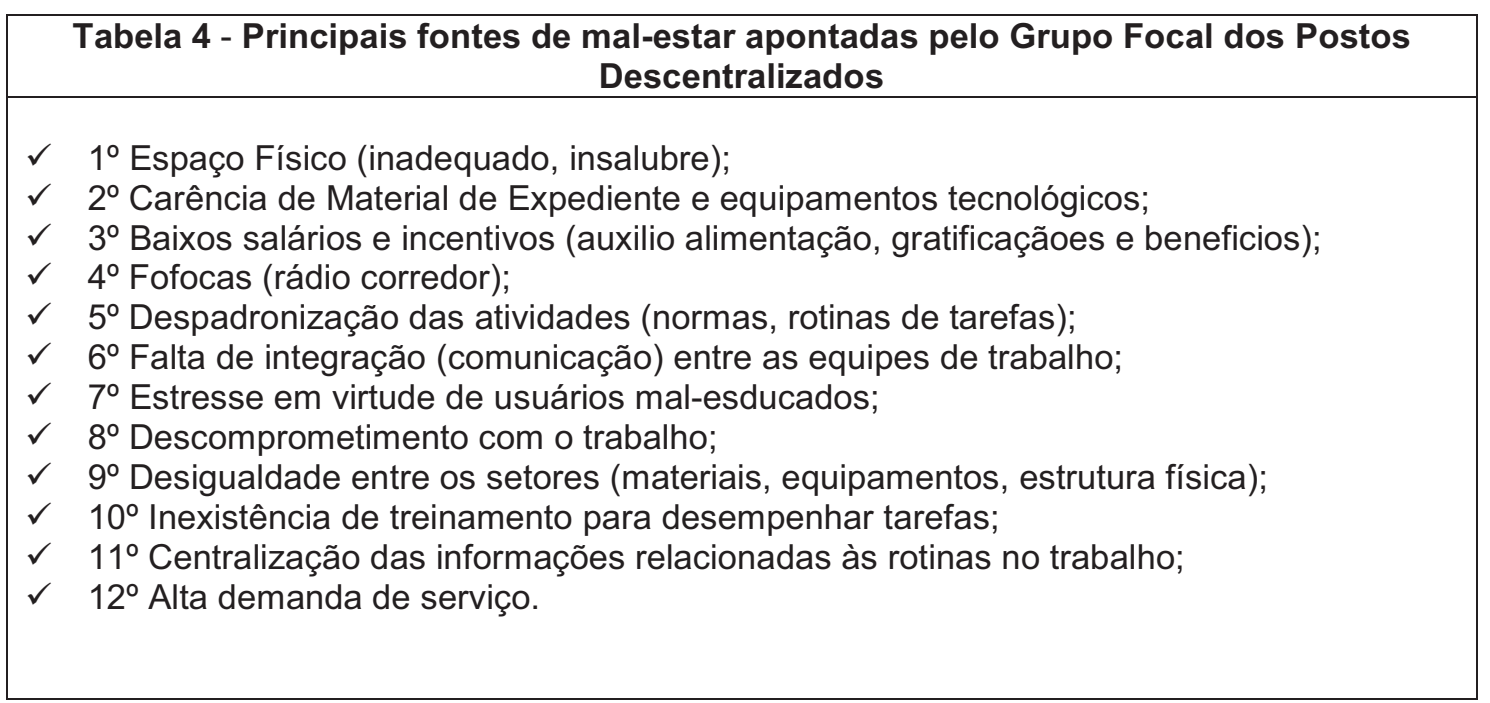

Ao comparar os dois quadros, foram observadas as seguintes fontes de mal-estar em comum nos dois grupos focais:

\author{
Tabela 5 - Principais fontes de mal-estar em comum apontadas pelos 2 grupos focais \\ $\checkmark$ Espaço físico (inadequado, insalubre) \\ $\checkmark \quad$ Carência de material de expediente e equipamentos tecnológicos \\ $\checkmark$ Baixos salários e incentivo (auxilio alimentação, gratificações e benefícios) \\ $\checkmark$ Descomprometimento com o trabalho \\ $\checkmark$ Centralização das informações relacionadas às rotinas no trabalho \\ $\checkmark \quad$ Inexistência de treinamento para desempenhar tarefas
}




\subsection{Vivências de mal-estar na administração pública pesquisada do serviço público federal:}

\subsubsection{Elementos Configuradores}

O conjunto de dados obtidos nos questionários reflexivos, e nas três etapas da técnica de Grupo Focal, evidenciou que as avaliações dos participantes desta pesquisa sobre o seu estado físico, psicológico e social ao contexto de serviço público são reveladores de vivências de mal-estar no trabalho.

Ao analisar os dados, identificaram-se os fatores que influenciam as vivências de mal-estar em três dimensões: (a) Condições de Trabalho; (b) Organização do Trabalho e; (c) Relações socioprofissionais.

\begin{tabular}{|c|c|c|}
\hline \multicolumn{3}{|c|}{$\begin{array}{c}\text { Tabela } 6 \text { - Fatores que Influenciam as Vivências de Mal-estar no Contexto de Produção } \\
\text { de Serviços da Unidade Administrativa do Serviço Público Federal pesquisada }\end{array}$} \\
\hline Condições de Trabalho & Organização do Trabalho & $\begin{array}{l}\text { Relações } \\
\text { Socioprofissionais }\end{array}$ \\
\hline $\begin{array}{ll} & \begin{array}{l}\text { Espaço físico } \\
\text { (inadequado, insalubre) }\end{array} \\
\checkmark & \text { Inexistência de } \\
\text { treinamento para } & \text { desempenhar tarefas } \\
\checkmark & \text { Baixos salários e } \\
\text { incentivo (auxílio } \\
\text { alimentação, gratificações } \\
\text { e benefícios) } \\
\checkmark \\
\text { Desprovimento de cursos } \\
\text { de capacitação }\end{array}$ & $\begin{array}{ll}\checkmark & \text { Carência de material de } \\
& \text { expediente e } \\
\text { equipamentos } & \\
\text { tecnológicos } \\
\checkmark & \text { Despadronização das } \\
& \text { atividades (normas, } \\
& \text { rotinas de tarefas) }\end{array}$ & 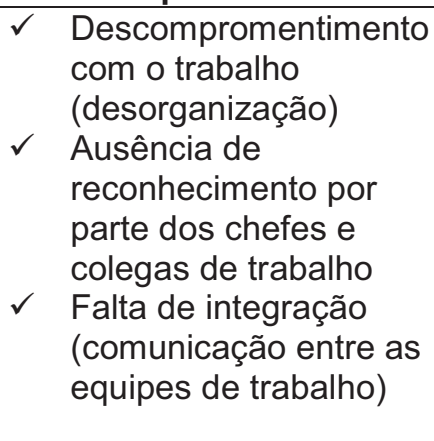 \\
\hline
\end{tabular}

Ao se comparar as três dimensões, percebe-se o papel contraditório e mediador que as relações sociais exercem na dinâmica do trabalho, uma vez que se reportam aos aspectos micro ou específicos (posto de trabalho, relações hierárquicas de comando etc.), mas também dizem respeito aos aspectos macro ou gerais (condições instrumentais de trabalho ou relações sociais de trabalho).

Conforme afirmado em Rodrigues, 2006; Alves Jr.; Aragão (2004), essas três dimensões analíticas têm servido de suporte conceitual para o desenvolvimento e execução de inúmeras pesquisas em Ergonomia da Atividade. Assim, tais dimensões fornecem as bases teóricas para se compreender a atividade de trabalho dos indivíduos. Segundo Ferreira \& 
Mendes (2003), essas variáveis nunca aparecem separadas. Estas buscam fornecer os parâmetros básicos, configuradores do Contexto de Produção de Bens e Serviços (CPBS), em que constituem as bases materiais e sociais nas quais se inscrevem a estrutura e a cultura organizacional.

As definições segundo Ferreira \& Mendes (2003) para as referidas variáveis são complexas em face da variabilidade, diversidade, dinâmica e imprevisibilidade de seus elementos, e podem, de acordo com o Contexto de Produção de Bens e Serviços (CPBS), apresentar papel e importância diferenciados.

Conforme Holman (2002), os custos gerados para a organização, originários de problemas como rotatividade e absenteísmo, aumentam a probabilidade de erros e contribuem para a perda de qualidade nos serviços, o que resulta em mal-estar para os trabalhadores. Assim, conforme mencionado anteriormente alem de existir uma relação entre as variáveis relacionadas a condições de trabalho, organização do trabalho e relações socioprofissionais, as representações de mal-estar e bem-estar oscilam no eixo saúde-doença e estão vinculadas a eficiência e eficácia das Estratégias de Mediação Individual e Coletiva (EMIC).

\subsection{Condições de trabalho na unidade administrativa do serviço público pesquisada}

Os elementos característicos da infra-estrutura, bem como apoio institucional e as praticas administrativas compõem a variável condições de trabalho, Ferreira \& Mendes (2003). Aspectos inadequados das Condições de Trabalho, conforme afirma Viana, Rocha, \& Gimenes (2004), contribuem para o aparecimento de conseqüências do custo físico que afetam a saúde dos trabalhadores.

O ambiente de trabalho dos participantes do grupo focal apresenta uma estrutura física precária devido à falta de manutenção. Na parte elétrica (figuras 1, 2 e 3) podem ser visualizados fios desencapados e fora da caixa de proteção, interruptores sem a tampa de proteção, e gambiarras. 
Figura 1 - Tampa de Proteção

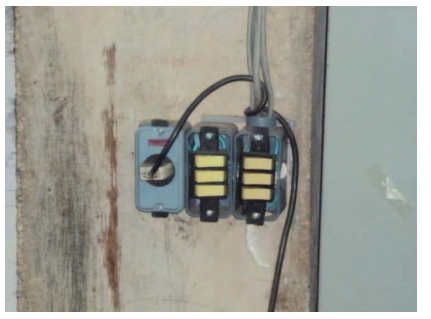

Figura 2 - Fios de Energias

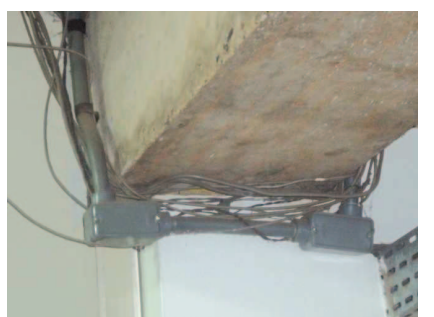

Figura 3- Gambiarras

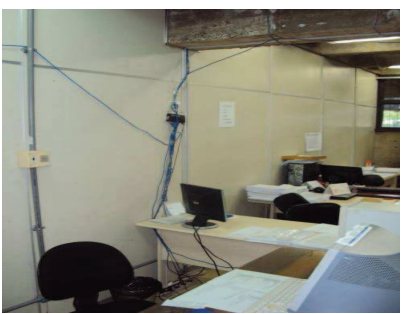

Nos tubos de encanamento (figuras 4, 5 e 6), encontram-se infiltrações, rachaduras, formação de estalactites, deterioração da estrutura. Alguns desses problemas podem ser visualizados nas imagens abaixo:

Figura 4 - Formação de Estalactites

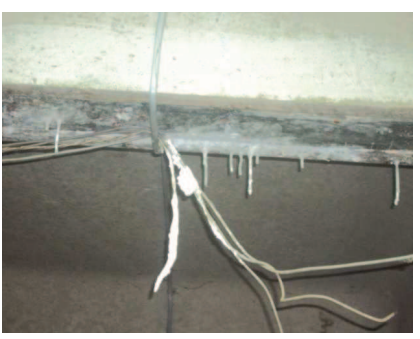

Figura 5 - Infiltração na Tubulação

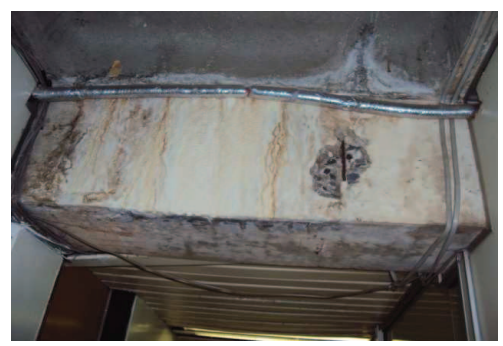

Figura 6- Rachaduras no Piso

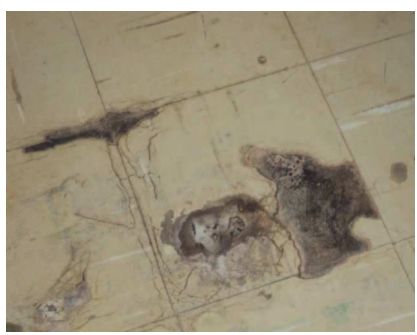

Em relação ao mobiliário (figuras 7, 8 e 9), suas condições são precárias e de características arcaicas: cadeiras muito antigas e rasgadas, e as mesas são inapropriadas para o uso de computador.

Figura 7 - Mesas Inapropriadas

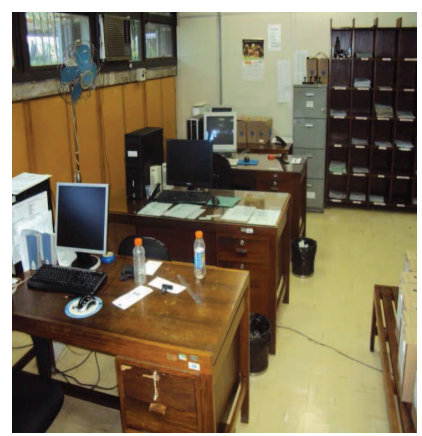

Figura 8 - Cadeira Rasgada

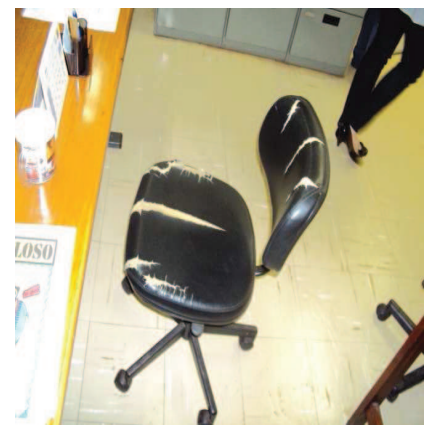

Figura 9 - Cadeira Antiga

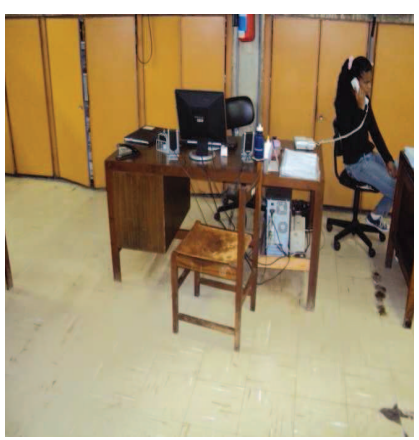


Os equipamentos (figuras 10, 11 e 12) são obsoletos, tais como: triturador de papel danificado, ar condicionado em condição precária, bebedouro inutilizável.

Figura 10 - Triturador de Papel Danificado

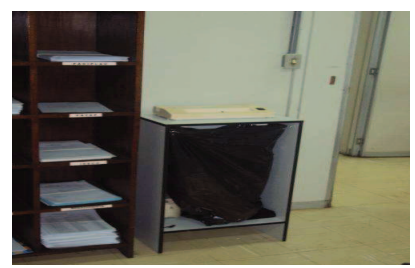

Figura 11 - Bebedouro sem Manutenção

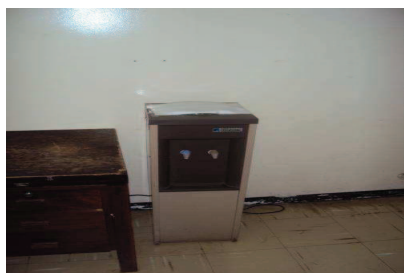

Figura 12 - Ar Condicionado em Condições Precárias

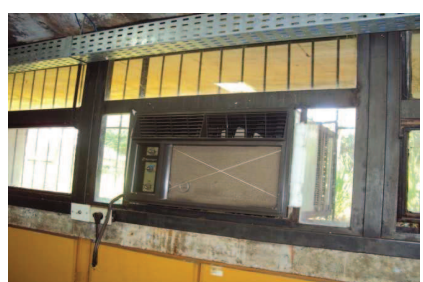

O espaço físico (figuras 13 e 14) é reduzido, o que causa tropeços nos fios dos computadores, da Internet e telefone.

Figura 13 - Espaço Reduzido

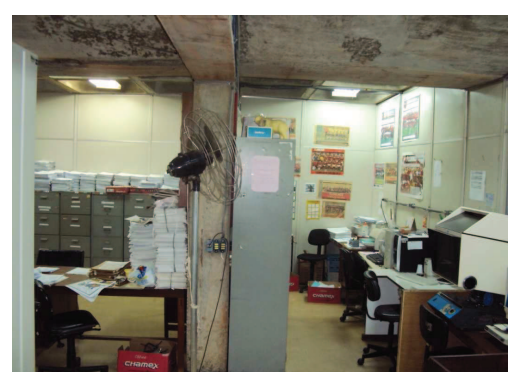

Figura 14 - Pouco Espaço, o que Possibilita Tropeços

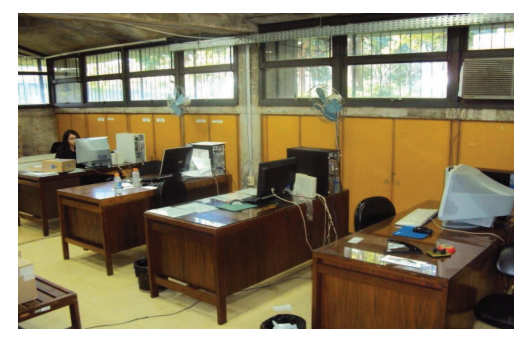

Os sanitários (figuras 15 e 16) são impróprios para utilização (sem porta, falta de sabonete e papel).

Figura 15 - Falta de Sabonete e Papel

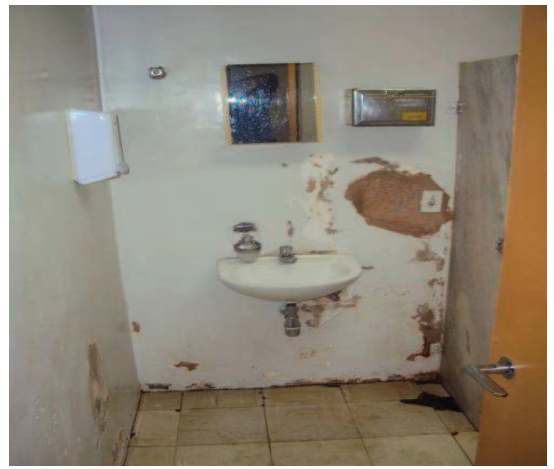

Figura 16 - Banheiro sem Porta

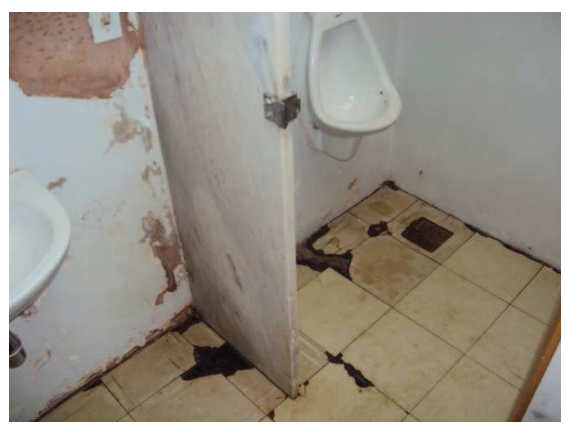


Falta de higienização no ambiente de trabalho (figuras 17 e 18), o que pode ocasionar doenças devido a o contato com fezes de ratos e baratas, necessitando assim a continua coleta de lixo.

Figura 17 - Coleta de Lixo

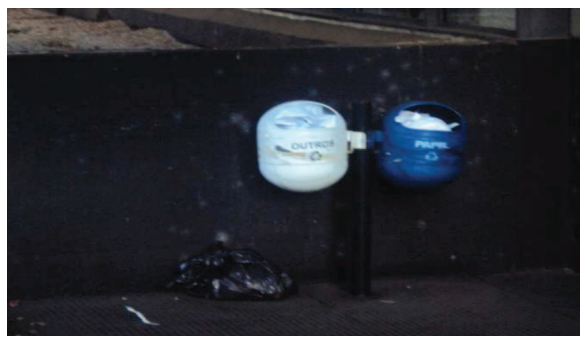

Figura 18 - Fezes de Ratos e Baratas

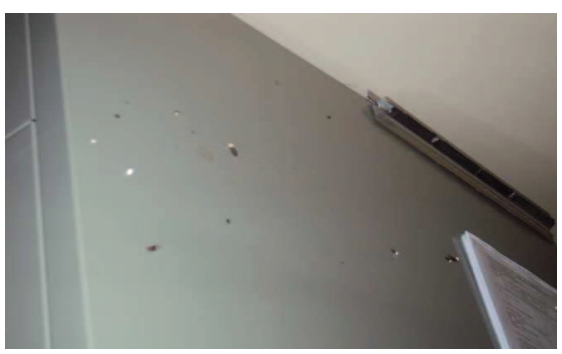

O arquivo é inadequado (figuras 19, 20 e 21), pois não comporta todas as pastas, aumentando assim, o risco de perda de informações.

Figura 19 - Falta de Arquivos

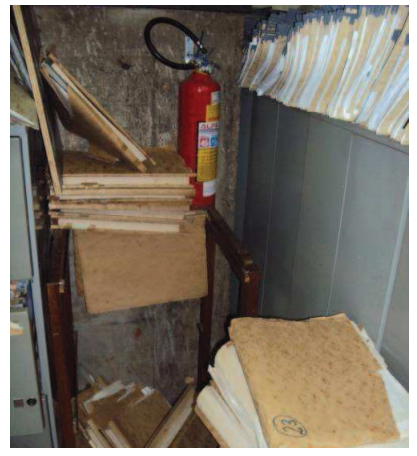

Figura 20 - Armários Lotados

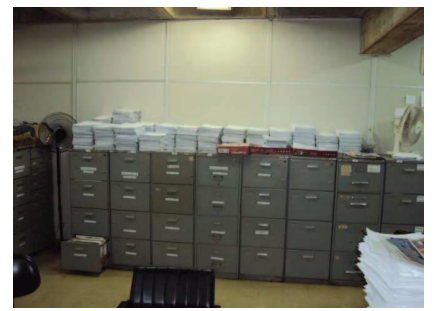

Figura 21 - Pastas de Registros

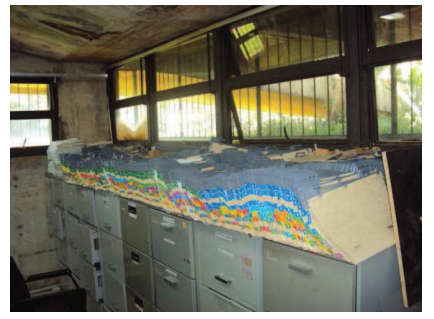

Local inadequado para caminhar (figuras 22, 23 e 24): grades quebradas e enferrujadas, piso emborrachado descolado.

Figura 22 - Grades Quebradas

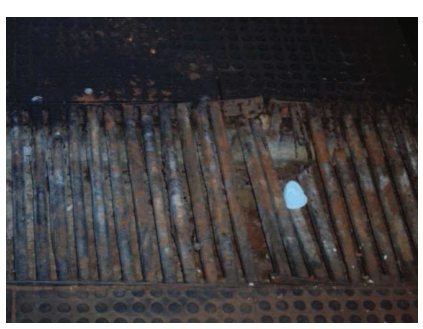

Figura 23 - Piso Descolado

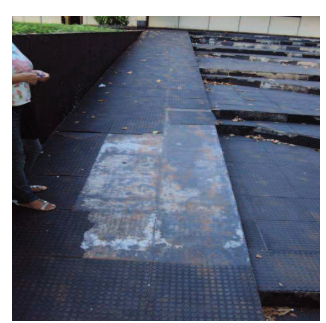

Figura 24 - Grades Enferrujadas

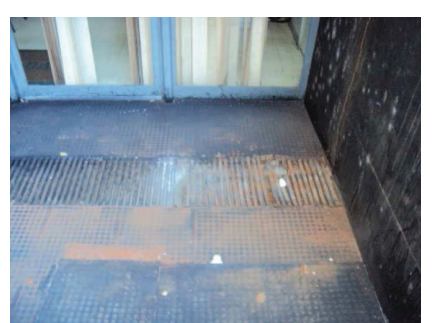


Conforme Ferreira (2004), condições de trabalho inadequadas deterioram a qualidade do contexto de trabalho aumentando o custo humano e colocando em risco o bem-estar dos trabalhadores. De acordo com o cenário vislumbrado nas imagens dispostas acima, pode-se verificar a falta das condições mínimas para execução das atividades de trabalho. Assim, pode-se inferir que essas atividades dos servidores e funcionários terceirizados dessa unidade administrativa do serviço público federal sofrem influências negativas das condições de trabalho a que estão sujeitas.

Os servidores e funcionários terceirizados precisam então adaptar suas atividades para que seja possível desempenhá-las em meio a essas ocorrências de problemas em seu ambiente de trabalho. Essas adaptações, aplicadas juntamente a novas atividades, configuram o que denominamos de "modos de lidar". Modos de lidar são as manifestações individuais ou coletivas que visam possibilitar a execução de tarefas em condições adversas àquelas que seriam as desejáveis para tal execução.

\subsection{Estratégia de Mediação Individual e Coletiva (EMIC) da unidade administrativa do serviço público federal pesquisado}

Os participantes da pesquisa apontam os seguintes modos de lidar para as principais fontes de mal-estar relacionadas às condições de trabalho:

$\checkmark$ Trazer material de escritório e limpeza de casa;

$\checkmark$ Buscar orientação para contornar o problema;

$\checkmark$ Incentivar os colegas a melhor se preparar;

$\checkmark$ Estudar para concursos;

$\checkmark$ Concentrar no trabalho e na harmonia do grupo.

Porém, os modos de lidar por si só não acabam com as fontes de malestar, eles apenas mitigam seus efeitos. Assim, as fontes de mal-estar geram conseqüências no trabalho a ser desempenhado.

As conseqüências apontadas pelos participantes da pesquisa para as principais fontes de mal-estar neste contexto de trabalho são:

$\checkmark$ Desmotivação e falta de esperança de que algum dia o espaço físico seja reformado;

$\checkmark$ Alergias, dores na coluna; 
$\checkmark$ O ambiente físico com o aspecto de sujeira;

$\checkmark$ Desinteresse para executar as tarefas

$\checkmark$ Problemas de saúde (estresse);

$\checkmark$ Atendimento ao público e o relacionamento interpessoal fica deficitário;

$\checkmark$ Falta de empenho no trabalho;

$\checkmark$ Indisponibilidade para ir trabalhar.

Como dito anteriormente, os modos de lidar são apenas uma solução paliativa para as fontes de mal-estar. Fazem-se necessárias medidas efetivas que solucionem de fato os déficits nas condições de trabalho. Em meio a isso, é importante verificar a opinião daqueles que estão inseridos no contexto do ambiente de trabalho a ser melhorado, visto que suas vivências, percepções e conhecimento das atividades de trabalho contribuem de maneira significativa na proposição de soluções para eliminar as fontes de mal-estar apontadas por eles.

Algumas sugestões indicadas pelos grupos focais são descritas a seguir, estas tem o objetivo de reverter ou minimizar as fontes de mal-estar apontadas pelos participantes do Grupo Focal relacionadas às condições de trabalho:

$\checkmark$ A Unidade Administrativa deve solicitar uma reforma para a diretoria;

$\checkmark$ Procurar as chefias para solucionar os problemas;

$\checkmark$ Comprometer-se mais com o trabalho;

$\checkmark$ Resolver os problemas para conseguir se concentrar nas atividades do trabalho.

\subsection{Organização do trabalho na unidade administrativa do serviço público pesquisada}

Com o novo cenário no mundo do trabalho, ainda prevalece uma realidade em um modelo taylorista de administração, Segundo Abrahão \& Santos (2004) a organização do trabalho não acompanha os avanços tecnológicos, ignorando as novas exigências trabalhistas.

Para a execução do trabalho os elementos da Organização do Trabalho podem contribuir ou dificultar este processo Abrahão e Torres (2005). Com a prescrição de normas, prazos e planejamento e desenvolvimento da tarefa, a organização do trabalho pode restringir as possibilidades de ação dos 
trabalhadores inviabilizando a manifestação de criatividade e do saber acumulado na resolução de problemas.

Para as fontes de mal-estar relacionadas à organização do trabalho os participantes da pesquisa apontam os seguintes modos de lidar:

$\checkmark$ Trazer material de limpeza e escritório de casa;

$\checkmark$ Buscar orientação para resolver o problema e melhor execução de tarefas;

$\checkmark$ Estudar para concursos para sair desta unidade administrativa.

As conseqüências apontadas pelos participantes da pesquisa para as principais fontes de mal-estar neste contexto de trabalho são:

$\checkmark$ Desmotivação e falta de esperança de que algum dia o espaço físico seja reformado;

$\checkmark$ Desmotivação para executar as tarefas;

$\checkmark$ Problemas de saúde;

$\checkmark$ Falta de vontade para trabalhar;

Algumas sugestões foram indicadas pelos participantes da pesquisa, a fim de reverter ou minimizar as fontes de mal-estar apontadas pelos participantes do Grupo Focal relacionadas à organização do trabalho:

$\checkmark$ A unidade administrativa deve solicitar uma reforma para a diretoria;

$\checkmark$ Orientação por parte da chefia dos serviços a serem executados;

$\checkmark$ Mudar alguns aspectos da lei, regimentos internos.

\subsection{Relações socioprofissionais na unidade administrativa do serviço público pesquisada}

Segundo Ferreira \& Mendes (2003), as relações socioprofissionais (ou interações socioprofissionais) manifestam-se como os elementos interacionais que denotam as relações socioprofissionais em um ambiente de trabalho, tais como as interações com colegas de trabalho, em diferentes níveis hierárquicos e também no mesmo nível, as interações com o público etc.

Quanto às fontes de mal-estar relacionadas às relações socioprofissionais foram apontados os seguintes modos de lidar:

$\checkmark$ Tentar manter as informações e os procedimentos de uma única forma; 
$\checkmark$ Orientação na importância de cumprir horário;

$\checkmark$ Repassar informações e conhecimentos acadêmicos.

Foram apontadas como conseqüências para as fontes de mal-estar no trabalho relacionadas às relações socioprofissionais as listadas abaixo:

$\checkmark$ Insegurança ao realizar as tarefas e procedimentos;

$\checkmark \mathrm{O}$ atendimento ao público e relacionamento interpessoal deficitário.

Foram sugeridas as seguintes ações para eliminar as fontes de mal-estar no trabalho relacionadas às relações socioprofissionais apontadas:

$\checkmark$ Capacitar os funcionários para que exerçam as tarefas de uma única forma;

$\checkmark$ Comprometimento com a instituição. 


\section{CONCLUSÃO}

Este estudo possibilitou a análise das fontes de mal-estar no trabalho, as Estratégias de Mediação Individual e Coletiva (EMIC), e a Qualidade de Vida no Trabalho (QVT) dos servidores públicos e funcionários terceirizados de uma unidade administrativa do serviço público federal.

A realização da pesquisa se deu por meio de analise documental, observações e também seguiu a técnica de Grupo Focal, no qual foram formados dois grupos focais contendo três etapas: formulário individual, subgrupos de discussão e síntese da discussão.

O objetivo deste estudo foi de identificar as fontes de mal-estar em uma unidade administrativa do serviço público federal e elencar as estratégias de mediação que possam gerar qualidade de vida neste ambiente de trabalho.

Foi proposto aos participantes desta pesquisa que refletissem a respeito da seguinte questão: "Quando penso no meu trabalho nesta unidade administrativa a principal fonte de mal-estar é...", a síntese dos dois grupos permitiu encontrar alguns traços em comum, tais quais:

$\checkmark$ Espaço físico (inadequado, insalubre);

$\checkmark$ Carência de material de expediente e equipamentos tecnológicos;

$\checkmark$ Baixos salários e incentivo (auxilio alimentação, gratificações e benefícios);

$\checkmark$ Descomprometimento com o trabalho;

$\checkmark$ Centralização das informações relacionadas às rotinas no trabalho;

$\checkmark$ Inexistência de treinamento para desempenhar tarefas.

Após a identificação das principais fontes de mal-estar nessa unidade administrativa, foi proposto aos participantes que fizessem a seguinte questão: "A conseqüência para a fonte de mal-estar é...". Para esta questão buscou-se evidenciar os desafios que se opõem a promoção da qualidade de vida no trabalho, tais quais: o espaço físico desmotiva as rotinas de atividades dos trabalhadores, o ambiente parece sempre estar sujo, além de ser propicio a alergias, o mobiliário não é adequado e traz como conseqüência dores na coluna e outros problemas de saúde (estresse). Todas essas conseqüências prejudicam o atendimento ao público e o relacionamento interpessoal. 
A terceira questão proposta aos participantes da pesquisa foi "o modo de lidar com tal conseqüência é...”. Os participantes definiram que a melhor forma para lidar com as fontes de mal-estar dessa unidade administrativa é trazendo o material de limpeza e escritório de casa para não ter que conviver em um ambiente sujo, ou continuar realizando suas rotinas diárias, também indicaram que o modo de se tratar as informações deve ser de forma padronizada para evitar transtornos em relação aos procedimentos de rotina.

Em relação à questão "A sugestão para o problema relacionado à fonte de mal-estar é...", os participantes da pesquisa do grupo focal apontaram a necessidade de sistematizar e sugerir soluções a longo prazo para se evitar o mal-estar no trabalho, conforme abaixo:

$\checkmark$ A Unidade Administrativa deve solicitar uma reforma para a diretoria;

$\checkmark$ Procurar as chefias para solucionar os problemas;

$\checkmark$ Comprometer-se mais com o trabalho;

$\checkmark$ Resolver os problemas para conseguir se concentrar nas atividades do trabalho;

$\checkmark$ Orientação por parte da chefia dos serviços a serem executados;

$\checkmark$ Mudar alguns aspectos da lei, regimentos internos;

$\checkmark$ Capacitar os funcionários para que exerçam as tarefas de uma única forma.

Após a pesquisa, os resultados obtidos permitiram a elaboração do Diagnóstico do Contexto de Trabalho desta unidade administrativa do serviço público federal. Tal estudo teve como base teórica a Ergonomia da Atividade, pois esta fornece uma ferramenta teórica de fácil aplicação.

A Ergonomia da Atividade possui uma linha preventiva, seu diagnóstico permite a identificação de indícios de problemas no ambiente de trabalho que podem afetar a vida do trabalhador, assim são orientadas recomendação para normalizar o ambiente de trabalho agregando qualidade de vida aos trabalhadores.

Cabe salientar que o delineamento metodológico da pesquisa na qual foi usada para este trabalho pode ser considerado uma prática de Qualidade de Vida no Trabalho (QVT), pois sua realização se deu em uma unidade administrativa do serviço público federal e as percepções, observações e 
opiniões apontadas expressam os sentimentos desta sobre as fontes de malestar no trabalho.

Os resultados da pesquisa juntamente com as ações sugeridas pelos participantes do grupo focal fornecem aos dirigentes e gestores da unidade administrativa do serviço público federal estudada elementos consistentes para a concepção, o planejamento e a execução de ações voltadas para a prevenção do mal-estar no trabalho e a promoção da Qualidade de Vida no Trabalho (QVT) dos servidores e funcionários terceirizados que ali trabalham. 


\section{Referências}

ABRAHÃO, J. I. \& SANTOS V. O controle no trabalho e seus efeitos no bem estar e na produtividade. In: TAMAYO, A. (Org.). Cultura e Saúde nas Organizações. Porto Alegre: Artme, 2004.

ABRAHÃO, J. I. TORRES, C. C. Entre a organização do trabalho e o sofrimento: o papel de mediação da atividade. Revista Produção, v. 14, n. 03, p. 67-69. 2005

ALVES JR., R. T. Avaliação de Desempenho, Atividade de Atendimento ao Público e Custo Humano no Trabalho em uma Empresa Publica no Distrito Federal. 2005. Dissertação (Mestrado em Psicologia) - Instituto Psicologia, Universidade de Brasília, Brasília, 2005.

ARAGÃO, J. P. Exigências Cognitivas e Estratégias de Mediação em Auditória - Fiscal da Previdência Social no Distrito Federal: Errar é preocupantes, refiscalizar é pior. Dissertação (Mestrado em Psicologia) Instituto de Psicologia, Universidade de Brasília, Brasília, 2004.

CARDOSO, D. I. \& Stano, R.C.M. As relações éticas e a qualidade de vida no trabalho: uma questão de gestão. In: SIMPÓSIO ENGENHARIA DE PRODUÇÃO, 12, 2005, Bauru. Anais... Bauru: SP, 2005.

CHIAVENATO, I. Recursos Humanos. São Paulo: Atlas, 1983.

CHIESA, Ana Maria; CIAMPONE, Maria Helena Trench. Princípios gerais para a abordagem de variáveis qualitativas e o emprego da metodologia de grupos focais. A classificação internacional das práticas de enfermagem em saúde coletiva - CIPESC. Brasília: ABEN, 1999, p. 306-324.

DALL'AGNOL, C. M.; TRENCH, M. H. Grupos focais como estratégia metodológica em pesquisa na enfermagem. Rev. Gaúcha Enf., Porto Alegre, v.20, n.1, p. 5-25, 1999.

DINIZ, L. S. Vivências de mal-estar e bem-estar no trabalho em central de teleatendimento governamental. Dissertação (Mestrado em Psicologia Social do Trabalho) - Instituto de Psicologia, Universidade de Brasília, Brasília, 2006.

DEBUS, M. Manual para excelência em La investigacion mediante grupos focales. Washington: Academy for Educational Development, 1997.

FERNANDES, Eda. Qualidade de Vida no Trabalho: como medir para melhorar. Salvador: Casa da Qualidade, 1996. 
FERREIRA, M. C., \& MENDES, A. M. "Só de pensar em vir trabalhar, já fico de mau-humor: atividade de atendimento ao público e prazer-sofrimento no trabalho". Estudos de Psicologia, 2001.

FERREIRA, M. C. Serviço de Atendimento Ao Público: o que é? como analisálo? Esboço de uma abordagem teórico-metodológica em ergonomia. Revista Multitemas, Campo Grande, v.0, n. 16, p. 128-144, 2000.

FERREIRA, M. C.; SEIDL, Juliana. Mal - estar no Trabalho: análise da cultura organizacional de um contexto bancário brasileiro. Psicologia: Teoria e Pesquisa, Brasília, v. 25, n. 0, p. 245-254, 2009.

FERREIRA. M. C., Marcas do Trabalho e Bem-estar no Serviço de Atendimento ao Público. In: A. M. MENDES, L. O. Borges \& M. C. FERREIRA (org.). Trabalho em Transição, Saúde em Risco. Brasília: Universidade de Brasília, 2002.

FERREIRA, M. C.; MENDES, A. M. Ergonomia da atividade \& psicodinâmica do trabalho: um diálogo interdisciplinar em construção. In: FERREIRA, M. C.; MENDES, A M. Trabalho e riscos de adoecimento: o caso dos auditores fiscais da Previdência Social brasileira. Brasília: LPA, 2003. cap. 1, p. 11-25.

FERREIRA, M. C. \& MENDES, A. M. Trabalho e riscos de adoecimento: o caso dos Auditores-Fiscais da Previdência Social Brasileira. Brasília: LPA, Fenafisp, 2003.

FERREIRA, M, C. \& MENDES, A. M. Gestão com pessoas focadas na qualidade de Vida no Trabalho: Bem-estar, uma tarefa de todos. In: FÓRUM DE QUALIDADE DE VIDA, 1, Trabalhando e Vivendo com Qualidade. 2004, Brasília : BC Integral, Anais... Brasília: DF, 2004. p. 3-8.

FERREIRA, M. C. Bem - estar: Equilíbrio entre a cultura do trabalho prescrito e a cultura do trabalho real. In: TAMAIO, A. (org.). Cultura Organizacional e Saúde. São Paulo: Artmed, 2004. p. 127-157.

FERREIRA, M. C. Qualidade de vida no trabalho. In: Dicionário de Trabalho e Tecnologia. Porto Alegre: UFRGS, 2006b. p. 219-222.

FERREIRA, M. C. A ergonomia da atividade se interessa pela qualidade de vida no trabalho? Reflexões empíricas e teóricas. Cadernos de Psicologia Social do Trabalho, Brasília, v. 11, n.1, p.83-99, jun.2008.

FOLCH-LYON, E. and TROST, J.F. "Conducting focus groups sessions", In: Studies in Family Planning, v. 12. n. 12, dec., 1981. 
FRANÇA, A.C. LIMONGI. Qualidade de vida no trabalho: conceitos, abordagens, inovações e desafios nas empresas brasileiras, Revista Brasileira de Medicina Psicossomática. Rio de Janeiro, vol. 1, n. 2, p. 79-83, abr./mai./jun.1997

HOLMAN, D. (2002). Employee Wellbeing in call centers. Human Resourse Management Journal. London. v. 12.

IIDA, I. Ergonomia: projeto e produção. 6. ed. São Paulo: Edgard Blücher, 2000.

IERVOLINO, S.A.; PELICIONE, M. C. A utilização do grupo focal como metodologia qualitativa na promoção da saúde. Rev. Esc. Enf. USP. São Paulo, v.35, n.2, p. 115-21, jun. 2001.

MATTOSO, J. A desordem do trabalho. São Paulo: Scritta. 1995

MEIER, M. J. ; KUDLOWIEZ, S. Grupo focal: uma experiência singular. Texto \& Contexto Enf., Florianópolis, v.12, n.3, p. 394-399, 2003.

RESSEL, L. B.; GUALDA, D. M. R.; GONZALEZ, R. M. B. Grupo focal como uma estratégia para coletar dados de pesquisa em enfermagem. International Journal of Qualitative Methods. v. 1, n.2, spring, 2002. Disponível em: <http:// www.ualberta.ca/ ijqm>. Acesso em: 10 nov. 2009.

RODRIGUES, A. V. Exame Médico Periódico e Qualidade de Vida no Trabalho no Serviço Público Federal. Dissertação (Mestrado em Psicologia) Instituto de Psicologia, Universidade de Brasília, Brasília, 2006.

Rodrigues, M. V. C. Qualidade de Vida no Trabalho: evolução e análise no nível gerencial, Fortaleza: UNIFOR, 1991.

BOM SUCESSO, E. P. Trabalho e Qualidade de Vida. Rio de Janeiro: Qualitymark e Dunya, 1998.

IERVOLINO, S.A.; PELICIONE, M. C. A utilização do grupo focal como metodologia qualitativa na promoção da saúde. Rev. Esc. Enf. USP. São Paulo, v.35, n.2, p. 115-21, jun. 2001.

TOLFO, S.R., PICCININI, V. C. A QVT nas melhores empresas para trabalhar no Brasil: Disjunções entre teoria e prática. In: ENCONTRO NACIONAL DE ASSOCIAÇÃO DE PÓS-GRADUAÇÃO EM ADMINISTRAÇÃO, 26. 2002, Salvador. Anais... Salvador: ANPAD, 2002.

VERAS, V.S. Relações sociais de trabalho e custo humano da atividade: vivências de mal-estar e de bem-estar em serviço de teleatendimento 
governamental. Dissertação (Mestrado em Psicologia) - Instituto de Psicologia, Universidade de Brasília, Brasília, 2006.

VIANA, J. A R., ROCHA, L. E. \& Gimenes, M. J. F. Distúrbios osteomusculares relacionados ao trabalho localizados no pescoço em operadores de uma central de atendimento telefônico de uma empresa de transporte aéreo em São Paulo. In: CONGRESSO DA ASSOCIAÇÃO NACIONAL DE MEDICINA DO TRABALHO, 12, 2004, Goiânia. Anais... Goiânia: GO, 2004. 


\section{Anexo 1}

\section{Instrumentos}

Serão utilizados na coleta dos dados:

$\checkmark$ Grupo Focal

$\checkmark$ Entrevistas Individuais

$\checkmark$ Análise documental;

$\checkmark$ Observação livre e sistemática das situações de trabalho; e

$\checkmark$ Mensuração das variáveis físicas e ambientais.

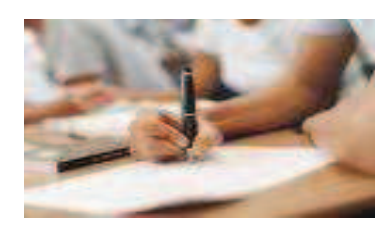

\section{Princípios Éticos}

Cabe enfatizar alguns aspectos éticos fundamentais que orientarão a conduta dos pesquisadores:

$\checkmark$ Respeitar a dignidade, a liberdade e a integridade das pessoas envolvidas no diagnóstico;

$\checkmark$ Resguardar às pessoas envolvidas o direito de ter acesso aos resultados do trabalho, após o seu encerramento;

$\checkmark$ O sigilo quanto à identificação dos participantes e unidades administrativas envolvidas.

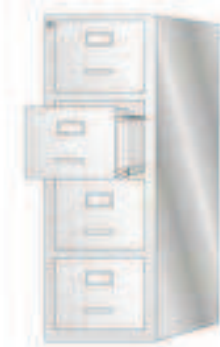

Universidade de Brasília (UnB)

\section{Equipe Realizadora}

Fernanda Freires Miranda, Pós-graduanda do curso em Gestão Universitária (Especialização) da Universidade de Brasília, servidora da Universidade de Brasília prestando serviços na Secretaria de Administração Acadêmica (SAA), no Posto Avançado da FACE.

E-mail: fmiranda@unb.br

Giovanni Carluccio de Souza, Pósgraduando do curso em Gestão Universitária (Especialização) da Universidade de Brasília, servidor da Universidade de Brasília prestando serviços no Decanato de Pesquisa e PósGraduação (DPP), no qual faz parte da Equipe do Programa de Iniciação Cientifica - PROIC.

E-mail: giovanni@unb.br

\section{Orientador}

Prof. Dr. Mário César Ferreira

Psicólogo do Trabalho, pós-doutor em Ergonomia Aplicada à Qualidade de Vida no Trabalho (QVT) pela Université Paris 1 (Sobornne, Paris, França)

E-mail: mcesar@unb.br

Colocamo-nos à disposição para responder dúvidas e receber comentários e/ou sugestões sobre o nosso projeto de diagnostico.

Agradecemos, desde já, a atenção e o apoio dos servidores e funcionários terceirizados.

Esperamos contar com a participação de todos!

Atenciosamente

Fernanda Freires Miranda

Giovanni Carluccio de Souza

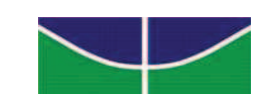

Universidade de Brasília (UnB)

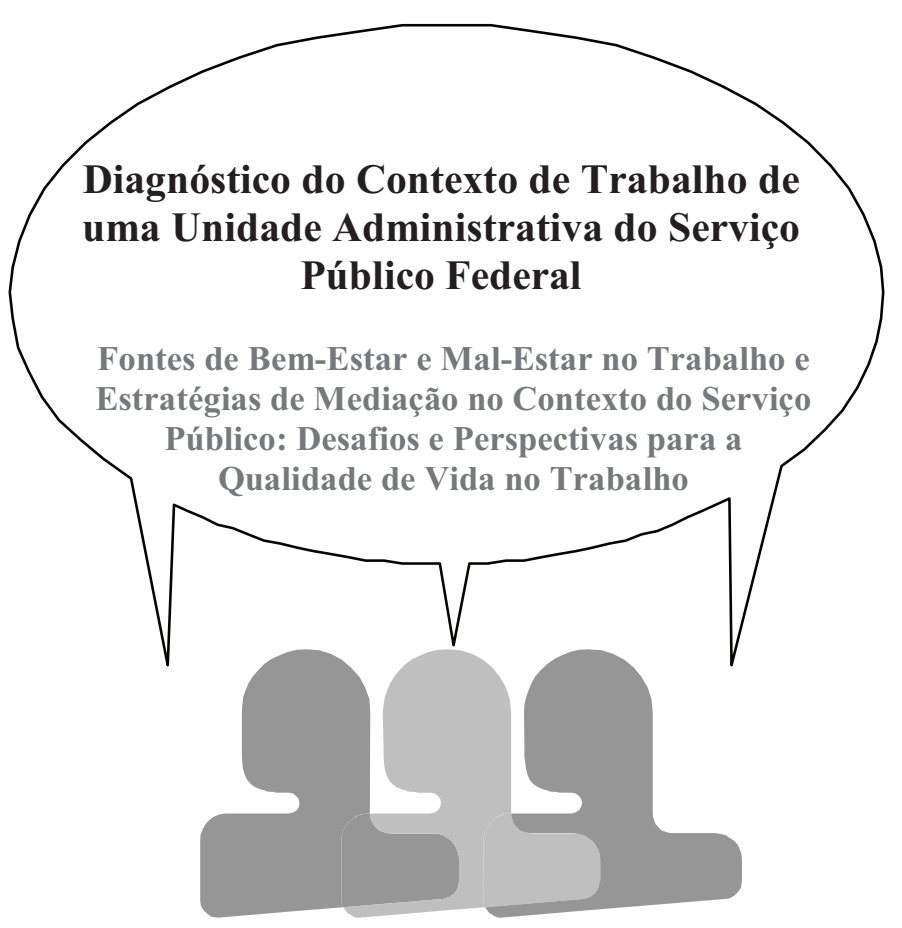

Fontes de Bem-Estar e Mal-Estar no Trabalho e Público: Desafios e Perspectivas para a 
O objetivo deste folder é apresentar sucintamente aos servidores e funcionários terceirizados o projeto Diagnóstico do Contexto de Trabalho da Unidade Administrativa do Serviço Público Federal

O projeto será conduzido pelos PósGraduandos do curso de Gestão Universitária (Especialização) Fernanda Miranda e Giovanni Carluccio, e contará com a supervisão acadêmica do Prof. Dr. Mário César Ferreira, coordenador do Grupo de Estudos e Pesquisas em Ergonomia Aplicada ao Setor Público (ErgoPublic), do Instituto de Psicologia da Universidade de Brasília.

\section{Objetivos do Diagnóstico do Contexto de Trabalho}

O objetivo geral do projeto é realizar um diagnóstico do contexto de trabalho de uma Administração Pública do Serviço Público Federal, visando gerar subsídios para o planejamento de ações voltadas para o BemEstar e a Qualidade de Vida no Trabalho (QVT) dos servidores e funcionários terceirizados, além da satisfação dos usuários.

O projeto tem o intuito de:

$\checkmark$ Mapear, com base na percepção dos servidores e funcionários terceirizados, os principais indicadores críticos existentes relativos às condições, organização e relações socioprofissionais de trabalho e suas conseqüências para o Bem-Estar, a eficiência e eficácia dos processos de trabalho;

$\checkmark \quad$ Identificar as principais fontes de BemEstar e Mal-Estar existentes;

$\checkmark$ As conseqüências das Fontes de BemEstar e Mal-Estar; $\checkmark$ As formas de lidar com as fontes de BemEstar e Mal-Estar

$\checkmark$ As soluções para as fontes de Bem-Estar e Mal-Estar; e

$\checkmark$ Gerar um conjunto de recomendações técnicas visando atenuar/eliminar os indicadores críticos existentes e agregar Qualidade de Vida no Trabalho (QVT).

A implementação do diagnóstico poderá gerar ganhos institucionais para Administração Pública do Serviço Público Federal a curto, médio e longo prazo com base nos seguintes aspectos:

$\checkmark$ Resgate da auto-estima do servidor e funcionário terceirizado, oferecendo a oportunidade de expor suas queixas e sugestões para o alcance do Bem-Estar e Qualidade de Vida no Trabalho (QVT).

$\checkmark$ Redução dos índices de erros, retrabalhos, perda de material, absenteísmo, aumento da rotatividade, licenças-saúde etc., impactando na produtividade e no custo final da prestação destes serviços;

$\checkmark$ Melhorias dos fluxos, rotinas e procedimentos internos, gerando maior eficiência no resultado global do serviço; e

$\checkmark$ Formação de uma imagem positiva e maior eficiência/eficácia no atendimento dos usuários.

\section{Metas da Pesquisa}

Ao término da execução do projeto será elaborado um "Relatório Técnico Executivo de Diagnóstico e Recomendações", contendo:

$\checkmark$ Uma síntese das principais fontes de Bem-Estar e Mal-Estar, conseqüências, formas de lidar e soluções constatadas;

$\checkmark$ Diretrizes para o planejamento de ações a curto, médio e longo prazo, voltadas para o Bem-Estar dos servidores e funcionários terceirizados, a satisfação do usuário e a eficiência/eficácia dos serviços prestados.

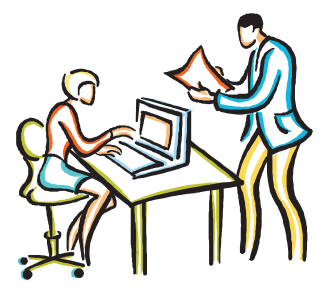

\section{Local de Realização do Projeto}

Unidade Administrativa do Serviço Público Federal

\section{Período de Execução}

O cronograma de diagnostico prevê um período total de execução de 4 semanas. O cumprimento destes prazos dependerá estritamente das condições oferecidas pelos participantes da pesquisa.

\section{Abordagem Metodológica}

A execução do projeto será baseada no seguinte enfoque metodológico:

\section{Participantes}

Farão parte do projeto os servidores e funcionários terceirizados lotados nesta Administração Pública.

\section{Etapas}

O projeto contemplará as etapas: (a) sensibilização dos servidores; (b) coleta de dados; (c) tratamento e análise dos dados coletados; (d) validação dos resultados; (e) discussão dos resultados; e (f) devolutiva aos participantes. 


\section{Anexo 2}

\section{Questões Etapa Individual}

Universidade de Brasilia (UnB)

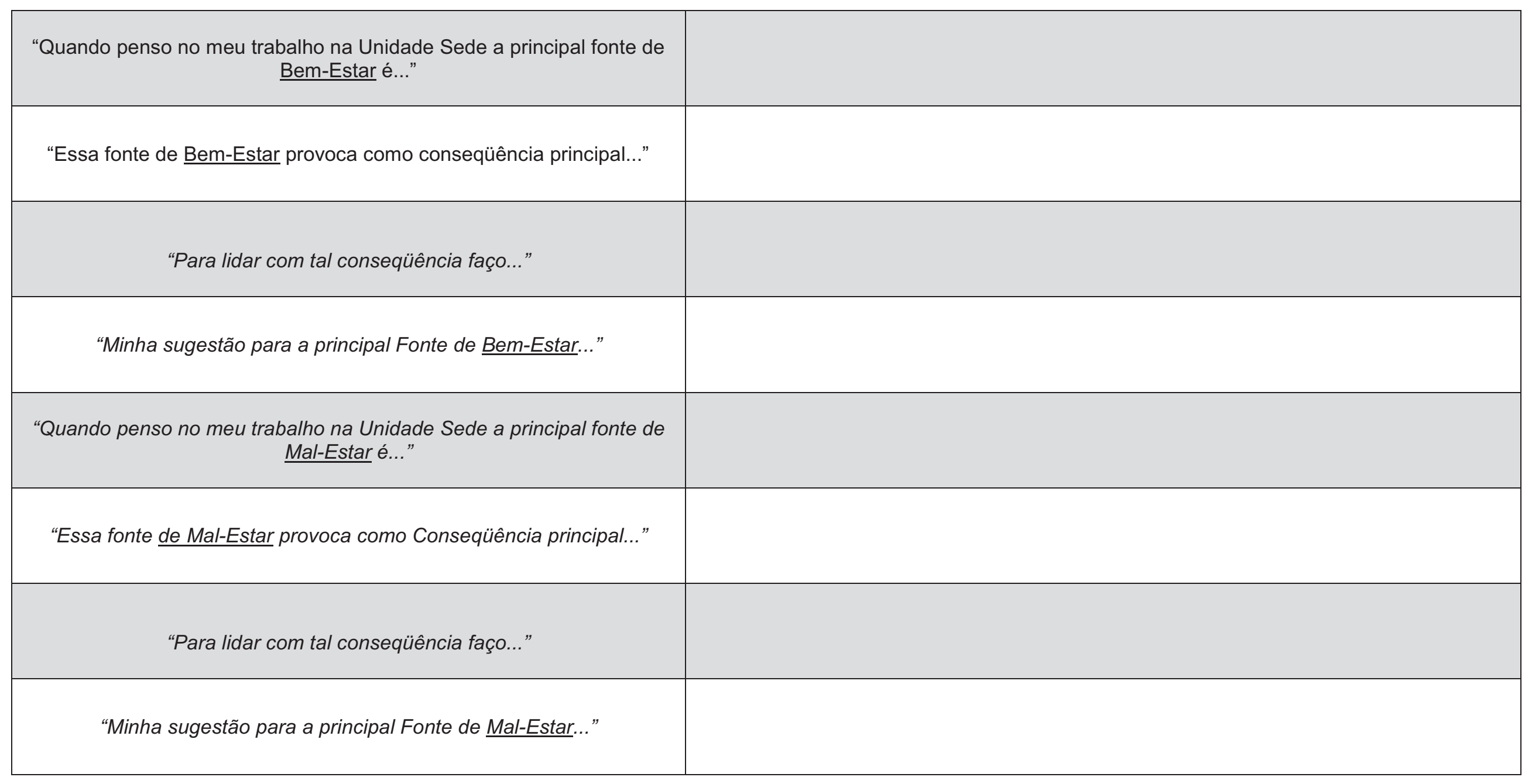

\section{Por favor responda os dados a sequir}

Idade: anos

Sexo: $\square$ Feminino $\square$ Masculino

Estado Civil:

Escolaridade:
Solteiro(a) $\square$ Casado(a) $\square$ Divorciado/separado(a) $\square \quad$ Viúvo(a) $\square$ Outros(a) $\square$

Ensino Fundamental $\square \quad$ Ensino Médio Incompleto $\square$ Ensino Médio Completo $\square$ Superior incompleto $\square$ Superior completo $\square$ Pós-graduação $\square$ 


\section{Anexo 3}

\section{Questões Etapa Individual}

Universidade de Brasilia (UnB)

\begin{tabular}{|c|c|}
\hline $\begin{array}{c}\text { "Quando penso no meu trabalho nos Postos Descentralizado } \\
\text { principal fonte de Bem-Estar é..." }\end{array}$ & \\
\hline \multicolumn{2}{|l|}{ "Essa fonte de Bem-Estar provoca como conseqüência principal..." } \\
\hline \multicolumn{2}{|l|}{ "Para lidar com tal conseqüência faço..." } \\
\hline \multicolumn{2}{|l|}{ "Minha sugestão para a principal Fonte de Bem-Estar..." } \\
\hline \multicolumn{2}{|l|}{$\begin{array}{c}\text { "Quando penso no meu trabalho nos Postos Descentralizados a } \\
\text { principal fonte de Mal-Estar é..." }\end{array}$} \\
\hline \multicolumn{2}{|l|}{ "Essa fonte de Mal-Estar provoca como Conseqüência principal..." } \\
\hline \multicolumn{2}{|l|}{ "Para lidar com tal conseqüência faço..." } \\
\hline "Minha sugestão para a principal Fonte de Mal-Estar..." & \\
\hline
\end{tabular}

\section{Por favor responda os dados a seguir}

\section{Idade: _ anos}

Sexo: $\square$ Feminino $\square$ Masculino

Estado Civil:

Escolaridade:
Solteiro(a) $\square$ Casado(a) $\square$ Divorciado/separado(a) $\square \quad$ Viúvo(a) $\square$ Outros(a) $\square$

Ensino Fundamental $\square \quad$ Ensino Médio Incompleto $\square$ Ensino Médio Completo $\square$ Superior incompleto $\square$ Superior completo $\square$ 


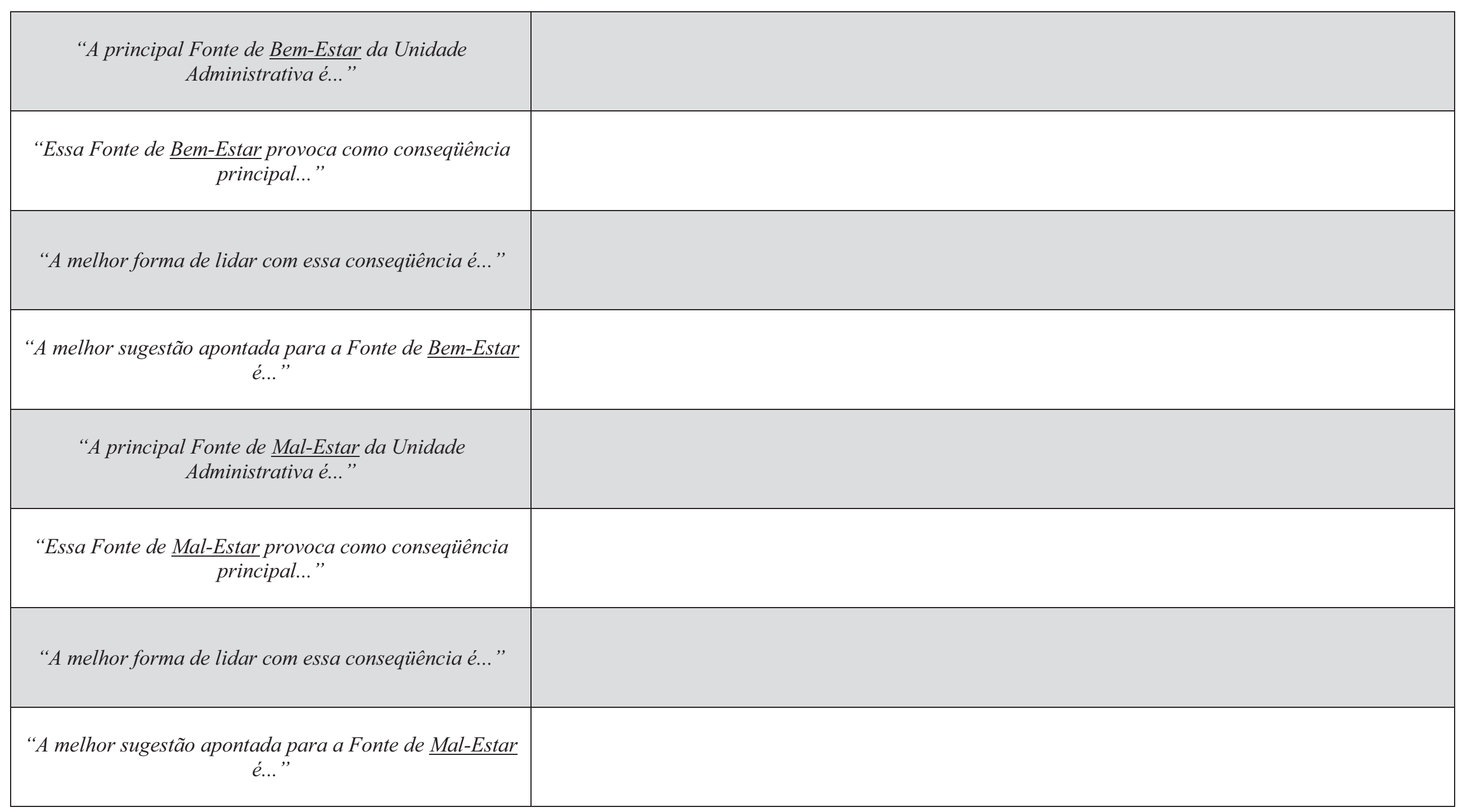


Anexo 5

\section{Diagnóstico do Contexto de Trabalho de uma Unidade Administrativa do serviço Público Federal}

Fontes de Bem-Estar e Mal-Estar no Trabalho e Estratégias de Mediação no Contexto do Serviço Público: Desafios e Perspectivas para a Qualidade de Vida no Trabalho

Relatório 


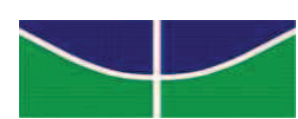

Universidade de Brasília

\section{Objetivos}

Conhecer a opinião dos servidores e funcionários terceirizados, sobre o contexto de trabalho de uma Unidade Administrativa do Serviço Público Federal, em oito aspectos:

$\checkmark$ Quando penso no meu trabalho na Unidade Administrativa a principal fonte de Bem-Estar é...

$\checkmark$ A conseqüência para a fonte de Bem-Estar é...

$\checkmark$ A forma de lidar com a conseqüência apontada para a fonte de Bem-Estar é...

$\checkmark$ A sugestão para o problema relacionado para fonte de Bem-Estar é...

$\checkmark$ Quando penso no meu trabalho na Unidade Administrativa a principal fonte de Mal-Estar é...

$\checkmark$ A conseqüência para a fonte de Mal-Estar é...

$\checkmark$ A forma de lidar com a conseqüência apontada para a fonte de Mal-Estar é...

$\checkmark$ A sugestão para o problema relacionado para fonte de Mal-Estar é...
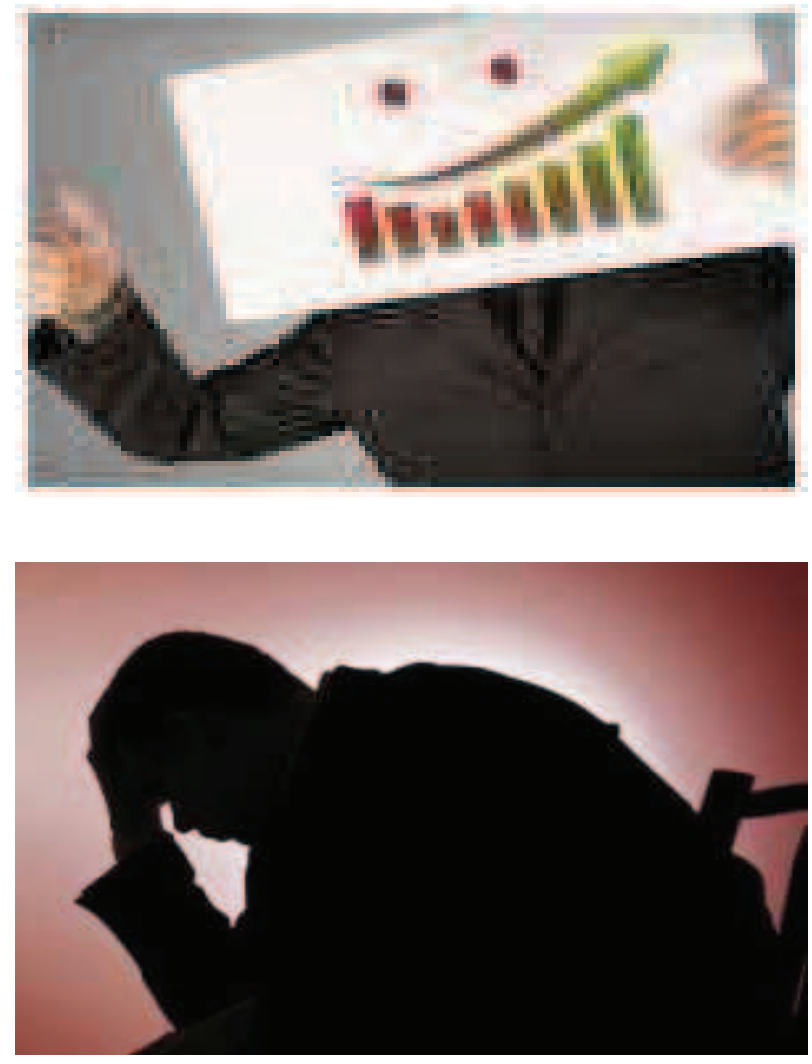


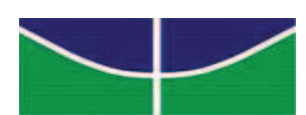

Universidade de Brasília

\section{Justificativa do Diagnóstico}

$\checkmark$ O sentimento de mal-estar no trabalho é a "porta de entrada" para a investigação da falta de qualidade de vida no trabalho. Nessa circunstância é que se manifestam as dificuldades e obstáculos em situações vivenciadas pelos trabalhadores, o que faz gerar a insatisfação, aborrecimento, absenteísmo;

$\checkmark$ No atual cenário competitivo organizacional, é clara a importância de se aperfeiçoar os recursos, aumentar a satisfação dos servidores e usuários, proporcionar um atendimento de qualidade e a plena satisfação. Surge então a necessidade de avaliar o contexto de trabalho;

$\checkmark$ A Qualidade de Vida no Trabalho (QVT) é um dos fatores que incorporam satisfação do indivíduo em sua atividade laboral e na humanização das situações relacionadas ao trabalho humano.

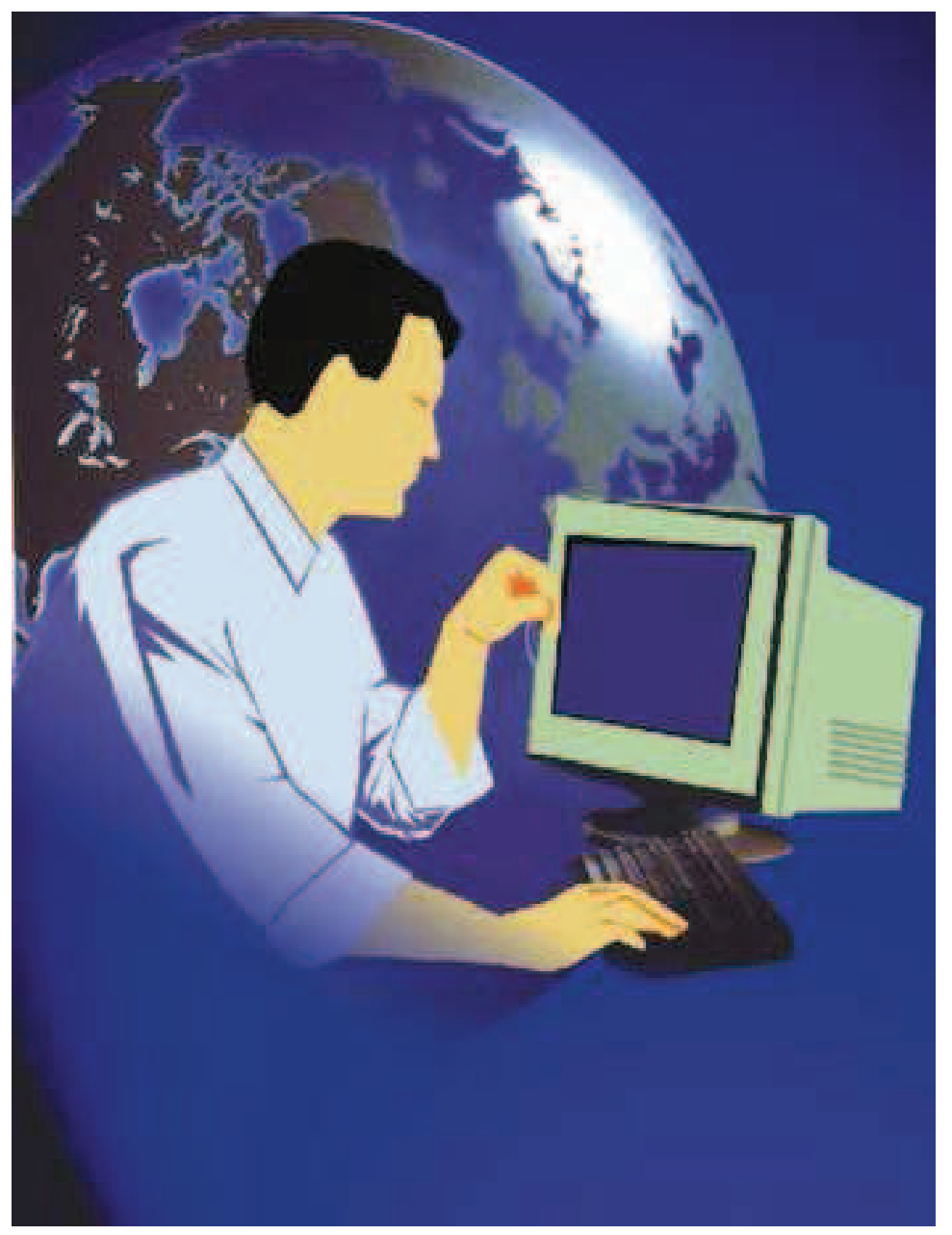




\section{Unidade Administrativa do Serviço Público Federal}

A unidade administrativa do serviço público federal que será objeto de estudo neste trabalho tem estimulado ao longo dos últimos anos o planejamento de seus órgãos como um instrumento de gestão indispensável à atualização de suas estruturas e das unidades que a integram e dando apoio aos gestores na elaboração de suas propostas de trabalho.

Tomando por base a missão Institucional, que é produzir, integrar e divulgar conhecimento, formando cidadãos comprometidos com a ética, a responsabilidade social e o desenvolvimento sustentável, define-se que a missão desta unidade administrativa, por ser uma unidade pertencente a um "todo", deve está alinhada à razão de ser da instituição da qual faz parte, auxiliando na melhoria da qualidade de vida de toda a comunidade interna e da comunidade externa.

Atualmente essa unidade possui um quadro de 85 (oitenta e cinco) colaboradores, divididos entre servidores públicos federais, funcionários terceirizados e estagiários, distribuídos na unidade sede e em seus 12 (doze) postos de atendimento descentralizado, em que todos respondem pelos serviços de atendimento ao público interno e externo. 


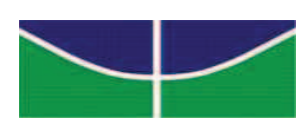

Universidade de Brasília

\section{Trajetória Metodológica}

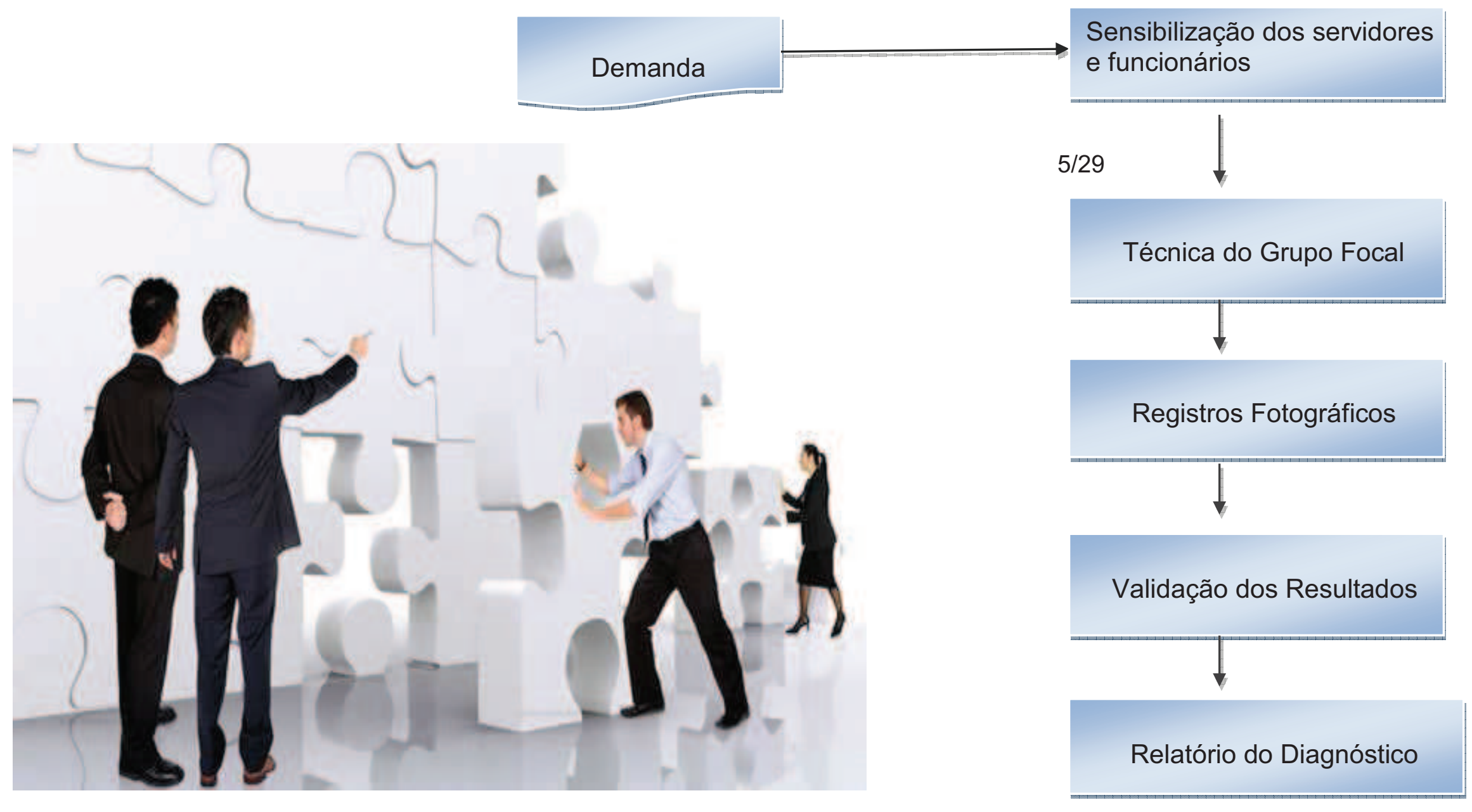




\section{Etapas do Grupo Focal}

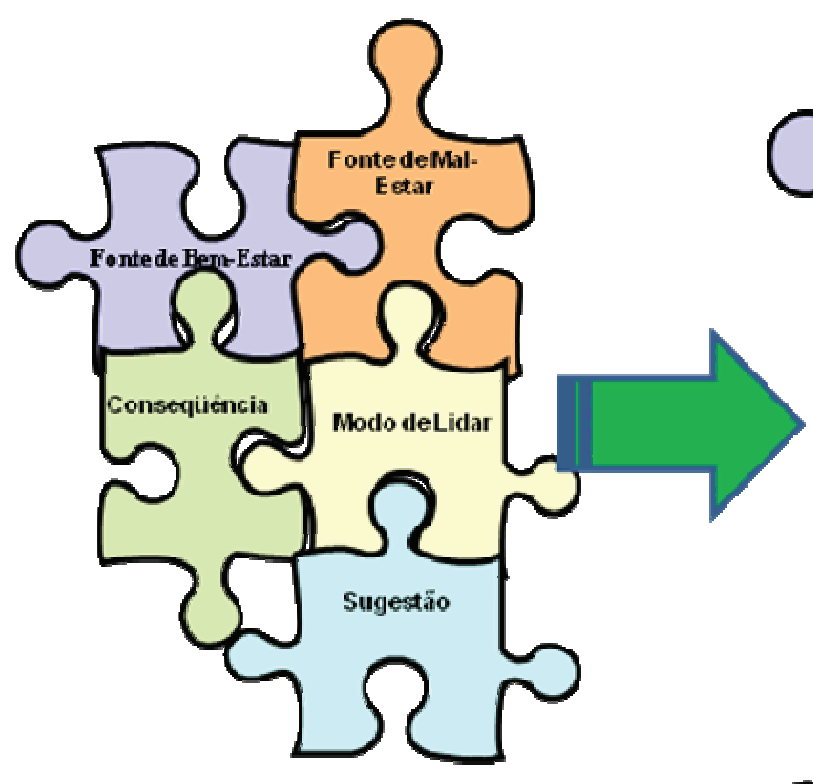

Etapa 1 Individual
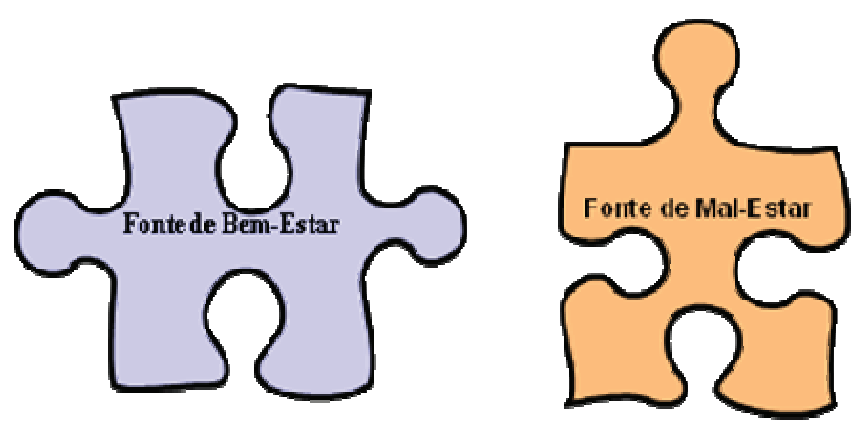

Etapa 2 Sub-Grupo

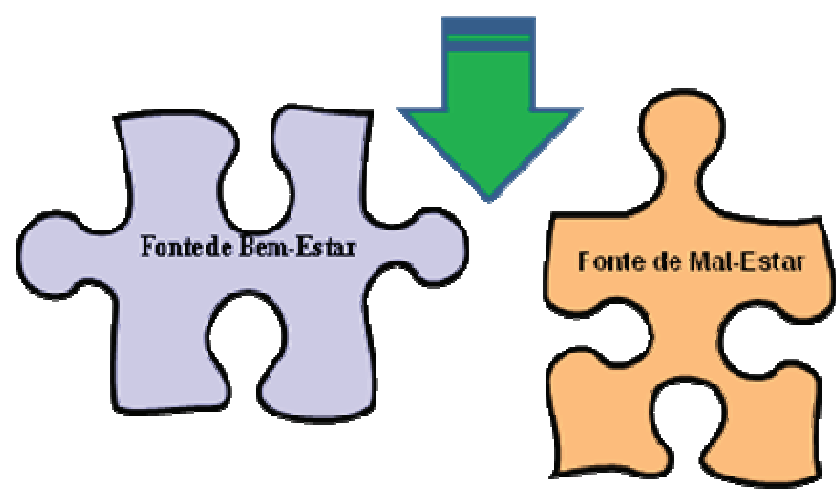

Etapa 3 Síntese do Grupo
Maio/2010
Diagnóstico do Contexto de Trabalho de uma Unidade Administrativa do Serviço Público Federal

\begin{tabular}{|l|l|l|l|}
\hline \multicolumn{4}{|c|}{ Perfil dos Participantes da Unidade Sede } \\
\hline \multicolumn{1}{|c|}{ Idade } & \multicolumn{1}{|c|}{ Sexo } & Estado Civil & \multicolumn{1}{|c|}{ Escolaridade } \\
\hline \multirow{3}{3}{$\begin{array}{l}\text { 33 anos em } \\
\text { média }\end{array}$} & 4 Feminino & 4 Casados & 2 Ens. Médio \\
& 10 Masculino & 9 Solteiros & S Diverior \\
& & 2 S. Incompleto \\
& & 5 P.Graduados \\
\hline
\end{tabular}

\begin{tabular}{|c|l|l|l|}
\hline \multicolumn{4}{|c|}{ Perfil dos Participantes dos Postos Descentralizados } \\
\hline Idade & \multicolumn{1}{|c|}{ Sexo } & Estado Civil & \multicolumn{1}{|c|}{ Escolaridade } \\
\hline \multirow{4}{*}{40 anos em média } & 5 Feminino & 6 Casados & 6 Superior \\
& 7 Masculino & 2 Solteiros & 4 S. Incompleto \\
& & 2 P.Graduados \\
\hline
\end{tabular}

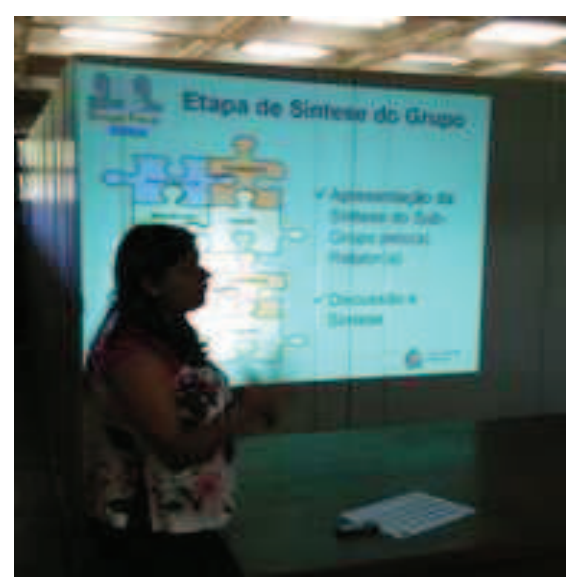

Fernanda Miranda e Giovanni Carluccio Supervisão acadêmica Prof. Dr. Mário César Ferreira 


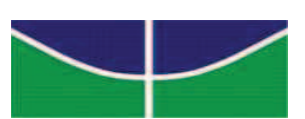

Universidade de Brasília

\section{Quais foram}
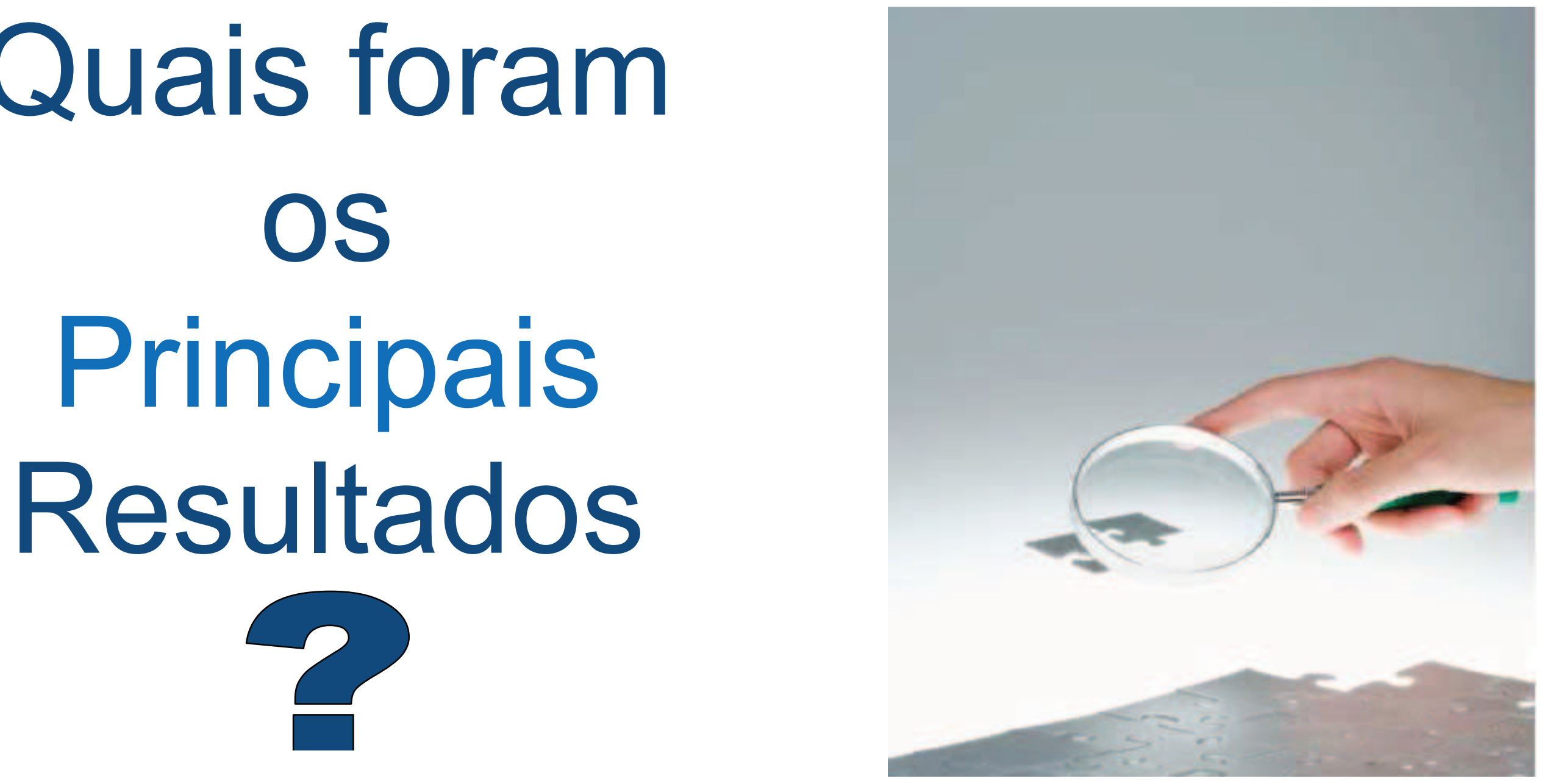


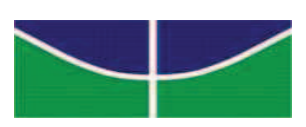

Universidade de Brasília

\section{Pontos em comum entre os Servidores e Funcionários Terceirizados da Unidade Sede e Postos Descentralizados}

A coleta de dados, por meio de entrevistas coletivas (participantes $\mathrm{N}=26$ ) realizada segundo a técnica Grupo Focal,

Evidenciou as Principais Fontes de Bem-Estar:

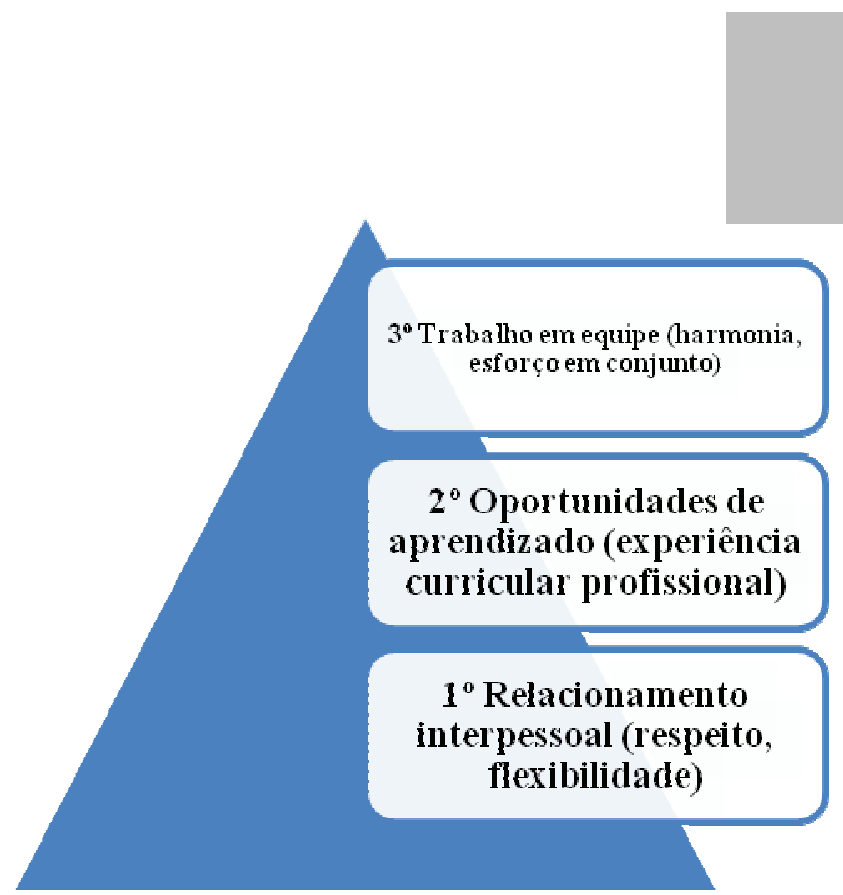

Unidade Sede

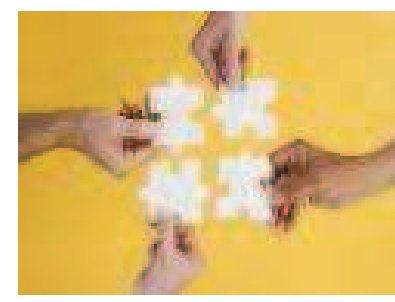

Maio/2010

\section{Questão Provocadora:}

"A principal fonte de Bem-estar na Unidade Administrativa é...".

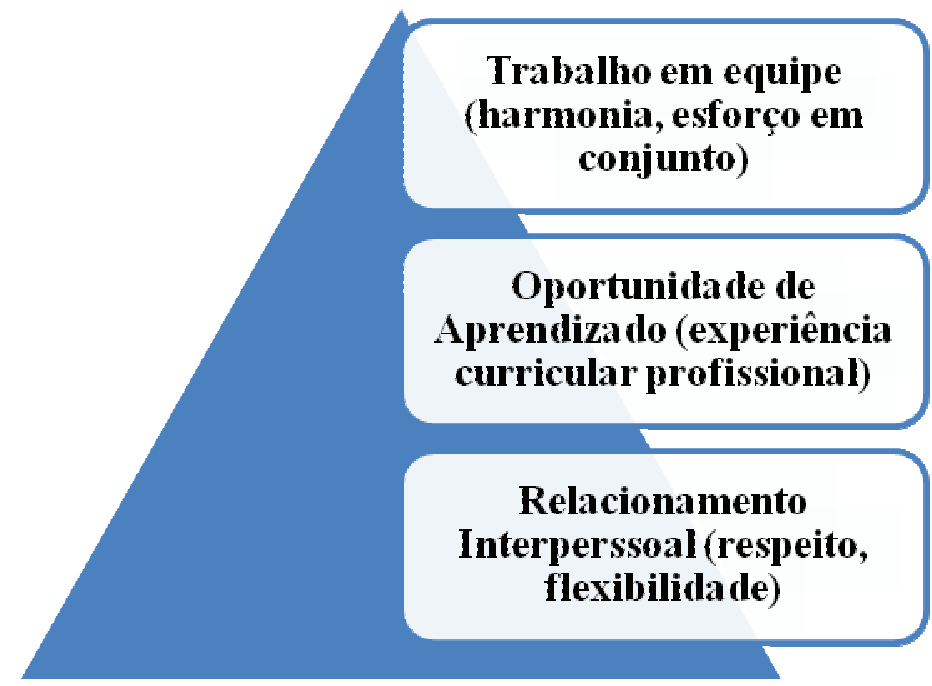

Em comum

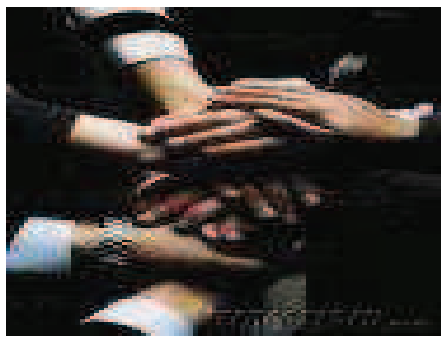

Diagnóstico do Contexto de Trabalho de uma Unidade Administrativa do Serviço Público Federal

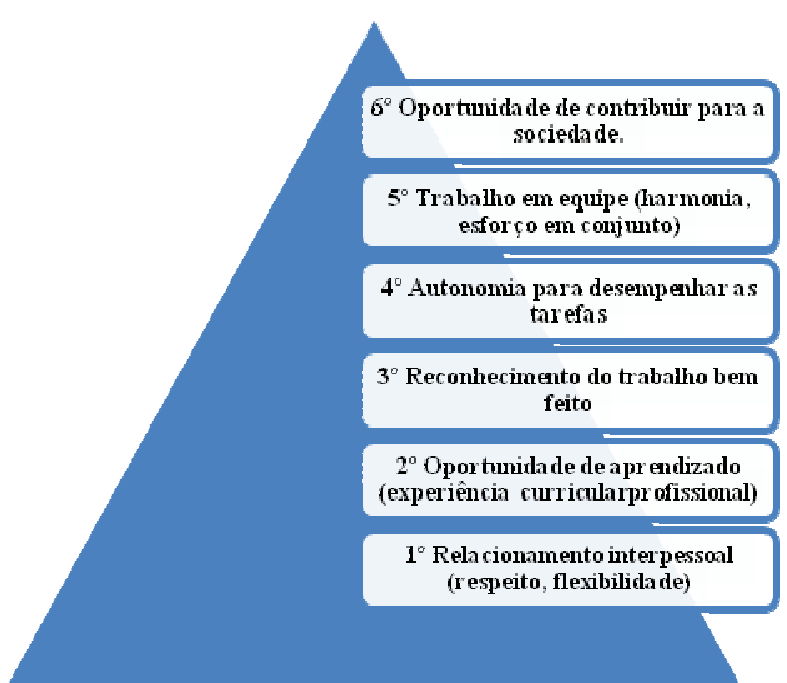

Postos Descentralizados

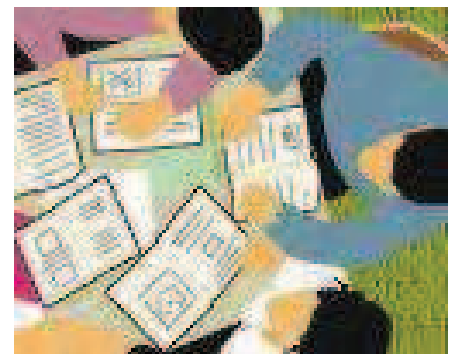

Fernanda Miranda e Giovanni Carluccio Supervisão acadêmica Prof. Dr. Mário César Ferreira 
Universidade de Brasília

O Que Pensam os Servidores e Funcionários Terceirizados sobre as Principais Fontes de Bem-Estar existentes na Unidade Sede e nos Postos Descentralizados

A coleta de dados, por meio de entrevistas coletivas (participantes $\mathrm{N}=26$ ) realizada segundo a técnica Grupo Focal, evidenciou as Principais Fontes de Bem-Estar:

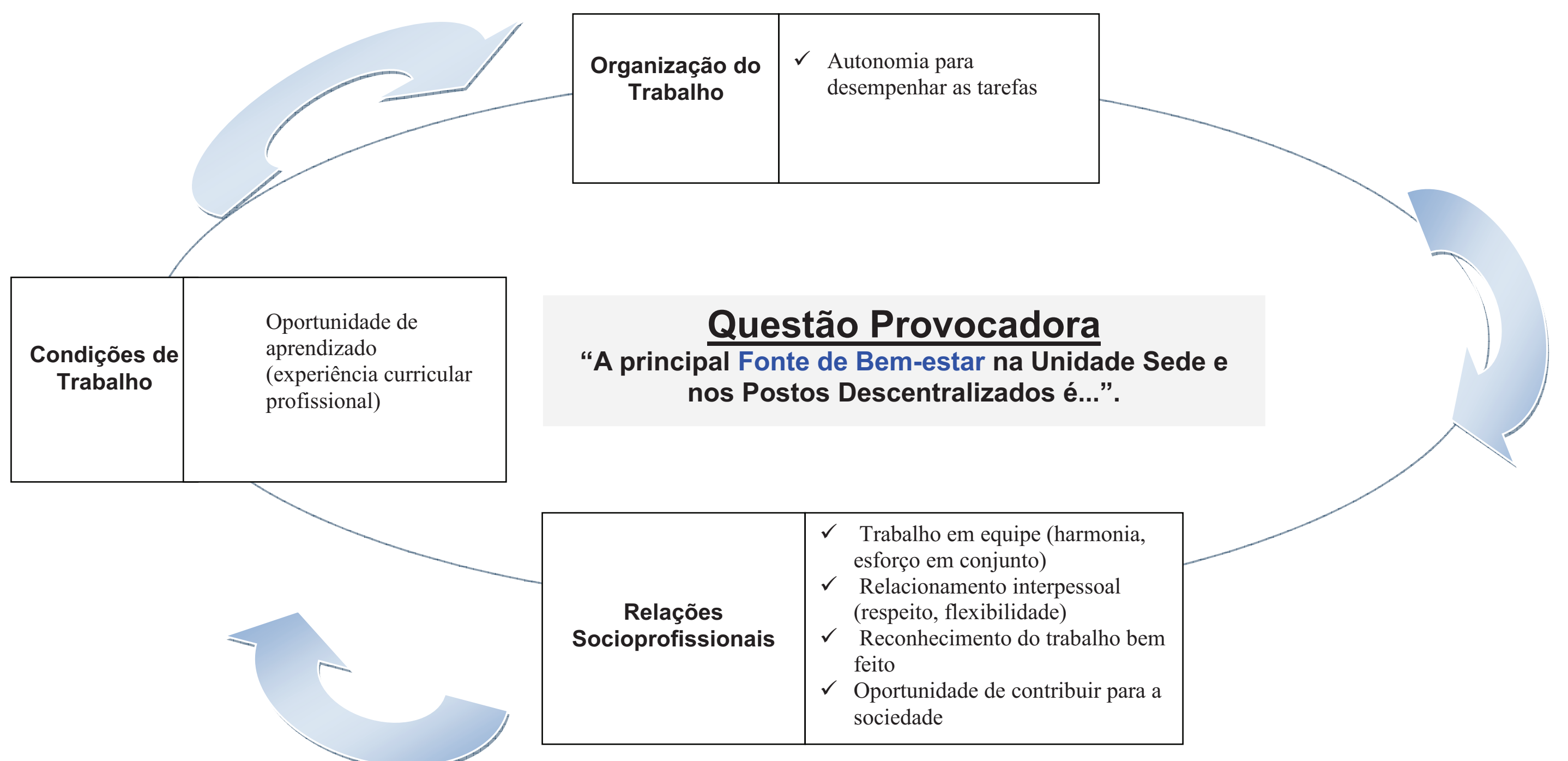


Modos de Lidar, Principais Conseqüências e Sugestões dos Servidores e Funcionários Terceirizados sobre as Principais Fontes de Bem-Estar existentes na Unidade Sede e nos Postos Descentralizados

\begin{tabular}{|c|c|c|c|}
\hline & Modo de Lidar & Conseqüências & Sugestões \\
\hline $\begin{array}{l}\text { Condições de } \\
\text { Trabalho }\end{array}$ & $\begin{array}{l}\text { Crescimento Pessoal; } \\
\text { Consultar aos setores para ter mais } \\
\text { conhecimento }\end{array}$ & $\begin{array}{c}\text { Enriquecimento curricular, cultural e } \\
\text { aprendizagem }\end{array}$ & $\begin{array}{l}\text { Remunerar bem e ser reconhecido pelo } \\
\text { o que faz }\end{array}$ \\
\hline $\begin{array}{l}\text { Organização do } \\
\text { Trabalho }\end{array}$ & Trabalhar de Forma Responsável & Responsabilidade e liberdade & $\begin{array}{l}\text { Estender esse trabalho } \\
\text { descentralizado, autônomo e } \\
\text { responsável para todos os setores }\end{array}$ \\
\hline $\begin{array}{c}\text { Relações } \\
\text { Socioprofissionais }\end{array}$ & $\begin{array}{c}\text { Desempenho da melhor maneira possível } \\
\text { do trabalho; } \\
\text { Mantenho meu padrão de convivência e } \\
\text { amizade; } \\
\text { Ter respeito com o próximo. }\end{array}$ & $\begin{array}{l}\text { Ânimo para realização do trabalho; } \\
\text { Bom desempenho das atividades; } \\
\text { A satisfação em trabalhar em um local } \\
\text { socialmente equilibrado; } \\
\text { Nunca abdicar dessa união. }\end{array}$ & $\begin{array}{c}\text { Manter afetividade com o meio de } \\
\text { trabalho; } \\
\text { Aplicação de Terapia de grupo para } \\
\text { manter um forte padrão de amizade; } \\
\text { União, e um ambiente agradável. }\end{array}$ \\
\hline
\end{tabular}


Questão Provocadora: "Quando eu penso no meu trabalho na Unidade Sede e nos Postos Descentralizados a Principal Fonte de Bem-Estar é...".

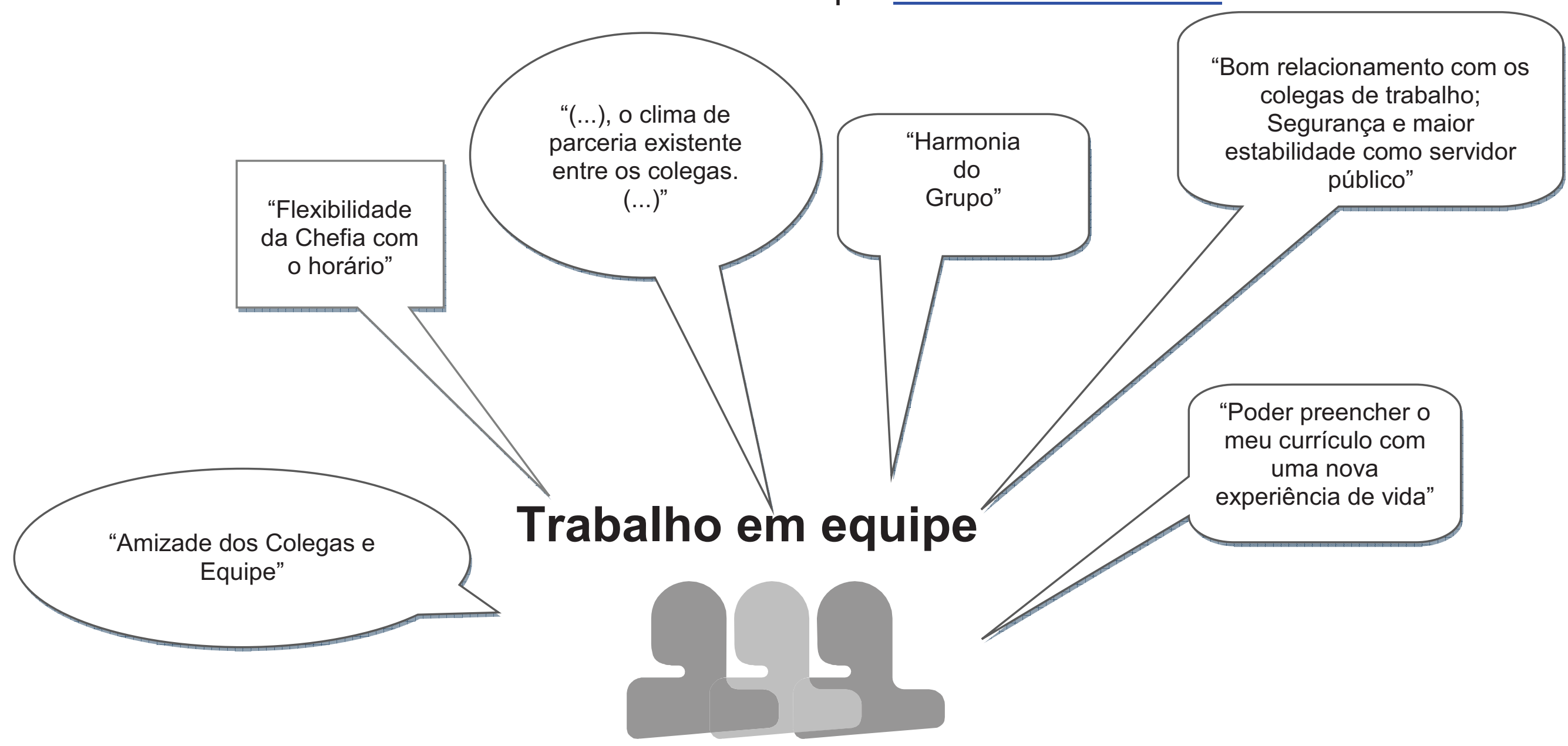


Pontos em comum entre os Servidores e Funcionários Terceirizados da Unidade Sede e dos Postos Descentralizados sobre as Principais Fontes de Mal-Estar

A coleta de dados, por meio de entrevistas coletivas (participantes $\mathrm{N}=26$ ) realizada segundo a técnica Grupo Focal, Evidenciou as Principais Fontes de Mal-Estar:

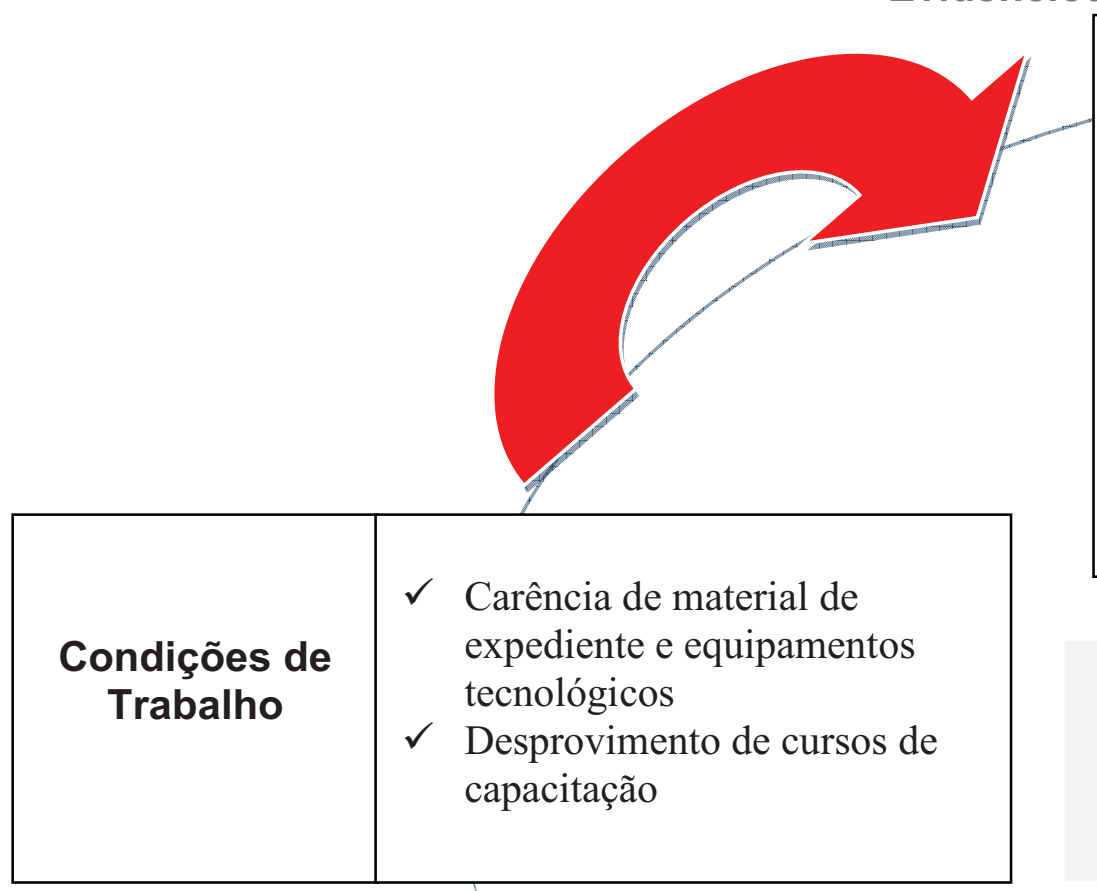

\begin{tabular}{|c|c|c|}
\hline $\begin{array}{c}\text { Organização do } \\
\text { Trabalho }\end{array}$ & $\checkmark$ & $\begin{array}{l}\text { Espaço físico (inadequado, } \\
\text { insalubre) }\end{array}$ \\
$\checkmark$ & $\begin{array}{l}\text { Inexistência de treinamento para } \\
\text { desempenhar tarefas }\end{array}$ \\
& $\checkmark \begin{array}{l}\text { Baixos salários e incentivo } \\
\text { (auxílio alimentação, } \\
\text { gratificações e benefícios) }\end{array}$ \\
& $\checkmark \begin{array}{l}\text { Falta de integração (comunicação } \\
\text { entre as equipes de trabalho) } \\
\text { Despadronização das atividades } \\
\text { (normas, rotinas de tarefas) }\end{array}$ \\
\hline
\end{tabular}

\section{Questão Provocadora}

"A principal Fonte de Mal-estar na Unidade Sede e nos Postos Descentralizados é...".

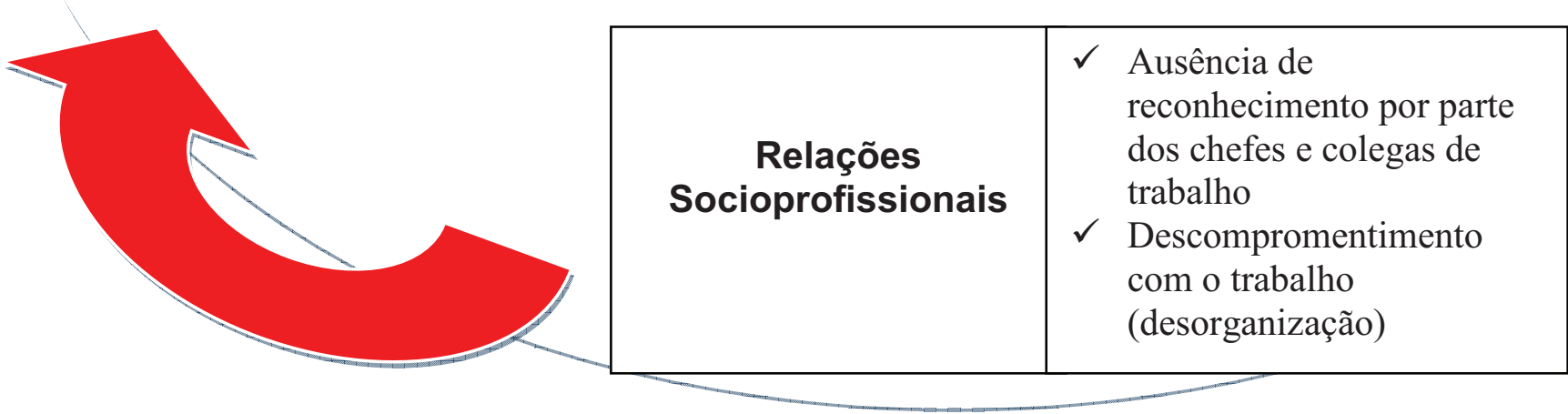




\section{Questão Provocadora: "Quando eu penso no meu trabalho na Unidade Sede e nos Postos Descentralizados a Principal Fonte de Mal-Estar é...”.}

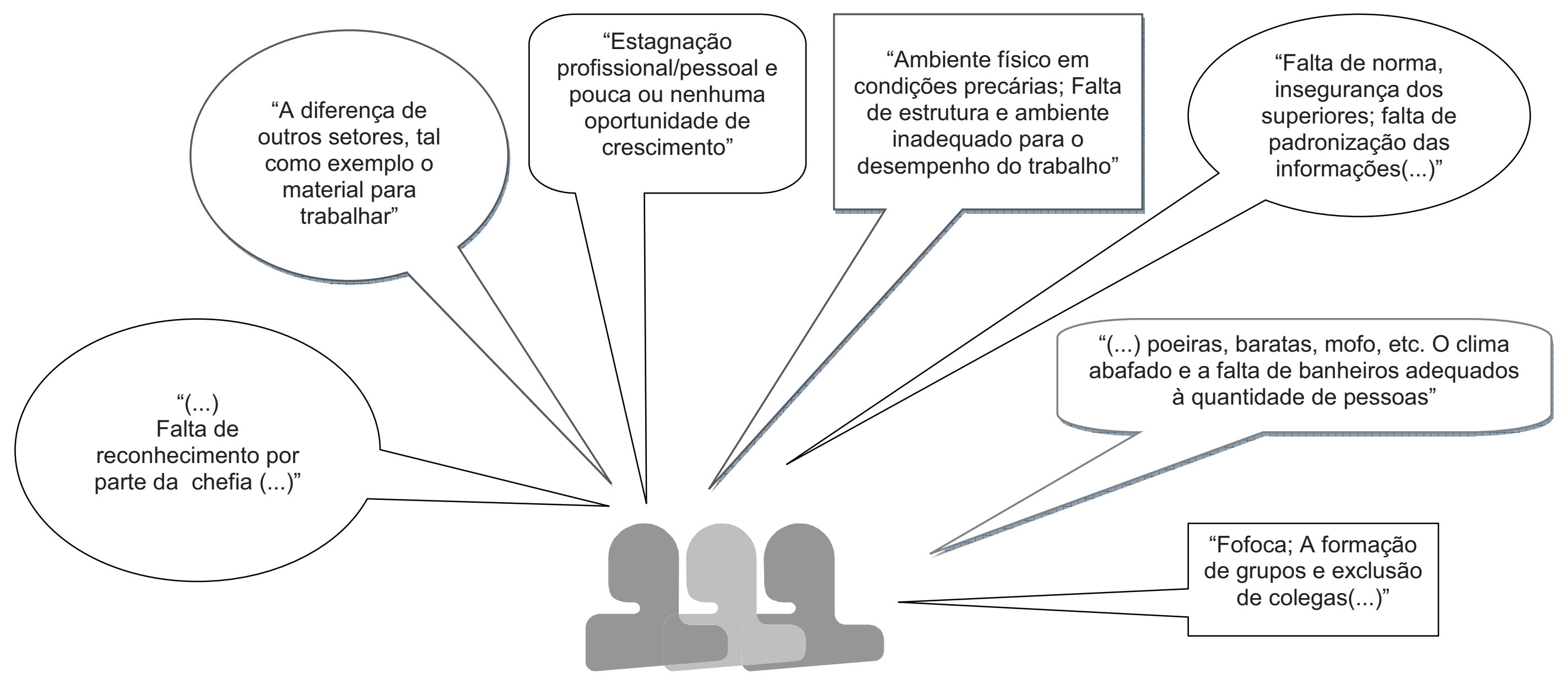




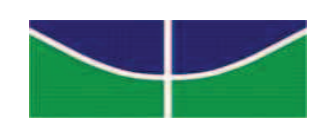

Universidade de Brasília

\section{Espaço Físico Inadequado}

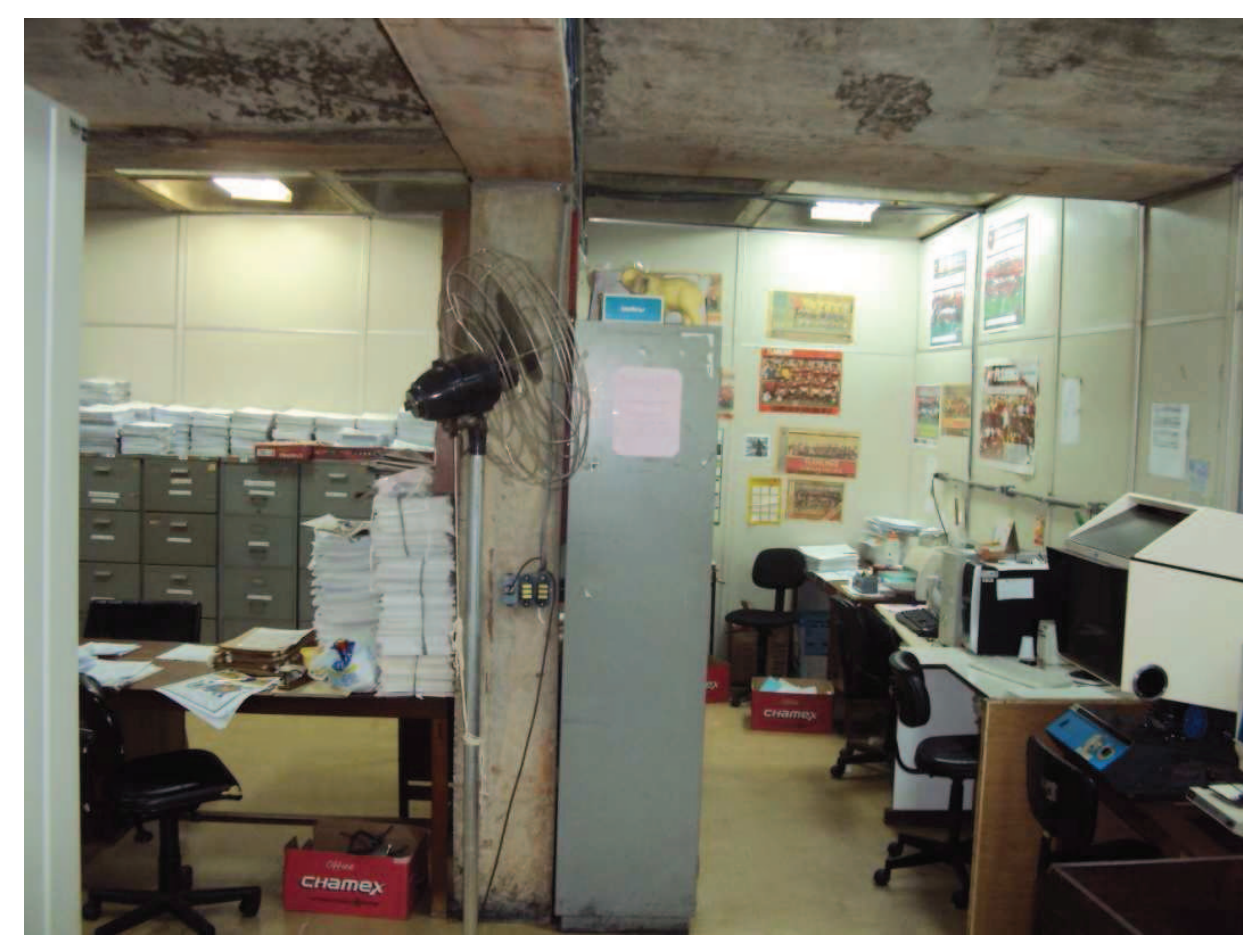

Espaço muito reduzido para se trabalhar.

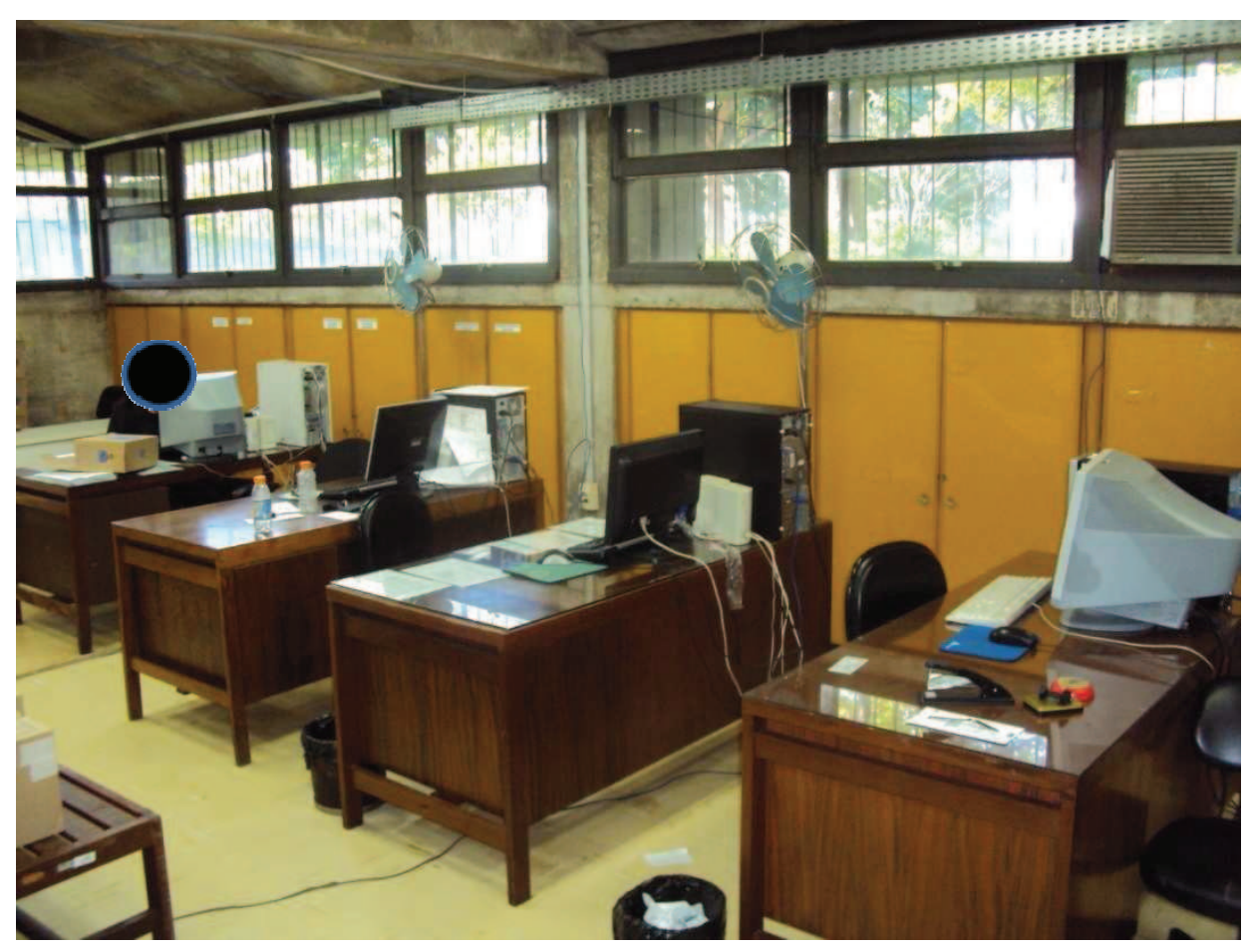

Pouco espaço entre mesas e cadeiras, 0 que possibilita tropeços nos fios dos computadores, da Internet e telefone. 


\section{Conclusão}

A importância de se conhecer a opinião dos servidores e funcionários terceirizados da Unidade Sede e dos Postos Descentralizados desta Unidade Administrativa do Serviço Público Federal, acerca das principais Fontes de Bem-Estar e Mal-Estar, suas conseqüências, o modo de lidar com essas conseqüências e sugestões para as fontes de Bem-Estar e Mal-Estar foi de fundamental importância para traçar o diagnóstico do contexto de trabalho existente nesta Unidade Administrativa.

O sentimento de Mal-Estar no trabalho foi relatado por todos os servidores e funcionários terceirizados que participaram do diagnóstico do contexto de trabalho da Unidade Sede e dos Postos Descentralizados desta Unidade Administrativa do Serviço Público Federal esse sentimento ocorre por vários motivos: espaço físico inadequado, falta de treinamento, baixos salários, falta de material de expediente, equipamentos tecnológicos etc.

O sentimento de mal-estar no trabalho reflete na qualidade de vida desses servidores e funcionários - que faz gerar doenças operacionais, insatisfação, desmotivação, aborrecimento, absenteísmo, insegurança, conforme relatado pelos próprios integrantes deste diagnóstico.

Conclui-se que a necessidade de avaliar o contexto de trabalho visando proporcionar subsídios para o planejamento de ações voltadas para o Bem-Estar e a qualidade de vida desses servidores e funcionários é fator essencial para a manutenção das relações socioprofissionais, no qual contribui para a satisfação e motivação no ambiente de trabalho. 


\section{Equipe Responsável}

Fernanda Freires Miranda, estudante da Especialização em Gestão Universitária da Universidade de Brasília, membro do Grupo de Estudos e Pesquisas em Ergonomia Aplicada ao Setor Público da Universidade de Brasília (ErgoPublic), servidora da Universidade de Brasília prestando serviços na Secretaria de Administração Acadêmica - SAA, no Posto Avançado da FACE - SAA-PA-FACE.

Giovanni Carluccio de Souza, estudante da Especialização em Gestão Universitária da Universidade de Brasília, membro do Grupo de Estudos e Pesquisas em Ergonomia Aplicada ao Setor Público da Universidade de Brasília (ErgoPublic), servidor da Universidade de Brasília prestando serviços no Decanato de Pesquisa e Pós-Graduação - DPP, no qual faz parte da Equipe do Programa de Iniciação Cientifica - ProlC.

Supervisão Acadêmica Professor Dr. Mário César Ferreira, Psicólogo do Trabalho com pós-doutorado em Ergonomia Aplicada à Qualidade de Vida no Trabalho (QVT) pela Université Paris 1 (Sobornne, Paris, França). Professor adjunto no Departamento de Psicologia Social e do Trabalho do Instituto de Psicologia da UnB. Pesquisador do CNPq, desenvolvendo atualmente o projeto (20082011) "Qualidade de Vida no Trabalho (QVT) no Contexto das Organizações Brasileiras: Construindo uma Métrica em Ergonomia da Atividade para Diagnóstico e Monitoramento". Têm diversos trabalhos de consultorias no âmbito do serviço público em instituições como: Detran - DF, Embrapa, Ministério das Relações Exteriores, Organização Pan americana de Saúde - Opas, Tribunal de Justiça do Distrito Federal e Territórios - TJDFT, Ministério da Educação - Mec, Banco de Brasília - BRB e Banco Central do Brasil. Na Universidade de Brasília tem orientado mestrandos e doutorandos que desenvolvem pesquisas aplicadas em empresas e organizações governamentais. É co-autor do livro "Trabalho e riscos de adoecimento: o caso dos auditores-fiscais da Previdência Social brasileira" (2003) Edições Ler, Pensar, Agir - LPA e co-organizador dos livros "A regulação social do trabalho" (2003), publicado pela Editora Paralelo 15 e "Trabalho em transição, saúde em risco" (2002) Editora da UnB. É também autor de três verbetes no Dicionário: Trabalho e Tecnologia (2006), Editora UFRGS. mcesar@unb.br; 율 (61) 9966-6687. 


\section{Referências Bibliográficas}

ARAUJO, P. M. Bem-estar no trabalho: Impacto das percepções dos valores organizacionais e da confiança do empregado na organização. Instituto de Psicologia da Universidade Federal de Uberlândia. Minas Gerais: Universidade de Uberlândia, 2008.

BASÍLIO, M. A. As relações entre bem-estar no trabalho e participação em programas organizacionais de promoção da saúde. 2005. Dissertação (Mestrado em Psicologia), Universidade Metodista de São Paulo, São Bernardo do Campo, 2005.

FERREIRA, M. C.; MENDES, A. M. Ergonomia da atividade \& psicodinâmica do trabalho: um diálogo interdisciplinar em construção.

FERREIRA, M. C.; MENDES, A M. Trabalho e riscos de adoecimento: o caso dos auditores fiscais da Previdência Social brasileira. Brasília: LPA, 2003. cap. 1, p. 11-25.

FERREIRA, M. C. (2002). Marcas do trabalho e bem-estar no serviço de atendimento ao público. Em Mendes, A. M.; Borges, L. O.

FERREIRA, M. C. (Orgs.), Trabalho em transição, saúde em risco. Brasília: Editora Universidade de Brasília, p. $163-183$.

FERREIRA, M. C.. O Sujeito forja o ambiente, o ambiente "forja" o sujeito: O trabalho como mediação indivíduo-ambiente em ergonomia da atividade. Em M. C. FERREIRA e S. Dal Rosso (Orgs.). A Regulação Social do Trabalho. Brasília: Paralelo 15,2003, p. 21-46.

FERREIRA, M.C., CARVALHO, R. S. \& SARMET, M. M. (1999). Ergonomia do serviço de atendimento ao público: Um estudo de caso. In Resumos do IX Congresso da Associação Brasileira de Ergonomia

FERREIRA, M. C.; MENDES, A. M. Brasília: Ler, Pensar e Agir, 2003.

FERNANDES, E.C. Qualidade de vida no trabalho: como medir para melhorar. $2^{\circ}$ Ed. Salvador: Casa da Qualidade Ed. Ltda, 1996.

VERAS, V. S. (2006). Relações Sociais de Trabalho e Custo Humano da Atividade: Vivências de Mal-estar e Bem-estar em serviço de Teleatendimento Governamental. Dissertação de Mestrado. Universidade de Brasília, Brasília. 